\title{
Pendeteksi Sikap pada Model Wahana Terbang menggunakan Inertial Measurement Unit
}

\author{
NANDANG TARYANA, DECY NATALIANA, ALFIE RIZKY ANANDA
}

Jurusan Teknik Elektro Institut Teknologi Nasional Bandung

E-mail : nandang@itenas.ac.id

\begin{abstract}
ABSTRAK
Penelitian ini membahas tentang aplikasi dari sensor gyroscope dan accelerometer yang merupakan komponen penyusun alat ukur inersial (inertial measurement unit) untuk mendeteksi sikap (attitude) pada wahana terbang tanpa awak. Sikap (attitude) memberikan 3 (tiga) informasi yaitu roll, pitch dan yaw. Penelitian ini bertujuan untuk melihat apakah alat pendeteksi sikap (attitude) sudah layak atau tidak digunakan pada wahana terbang yang akan dimodelkan yaitu dengan cara merancang sistem pengukuran/pendeteksi serta monitoring sikap (attitude) menggunakan software LabVIEW. Metode yang digunakan untuk mendeteksi kemiringan attitude merupakan pengabungan hasil pengukuran dari gyroscope dan accelerometer. Pengujian alat pendeteksi sikap dilakukan dengan cara mensimulasikan kinematika pergerakan wahana terbang. Berdasarkan hasil pengujian, alat pendeteksi sikap sudah layak digunakan pada wahana terbang $\mathrm{Hal}$ ini sesuai dengan simpangan rata - rata yang diperoleh dari hasil pengukuran rotasi pada sumbu $x$ (roll) sebesar $0,58^{\circ}$, rotasi pada sumbu $y$ (pitch) sebesar $0,53^{\circ}$ dan rotasi pada sumbu z (yaw) sebesar $7,64^{\circ}$.
\end{abstract}

Kata Kunci : Gyroscope, Accelerometer, Inertial Measurement Unit, attitude

\begin{abstract}
This journal elaborate the aplication of a gyroscope and accelerometer from an inertial measurement unit (IMU) for sensing attitude on an aircraft. Attitude give 3 (three) basic informations, that information are roll, pitch and yaw. The purpose of this journal is to analys if the attitude sensing device are suitble to be used on a model aircraft. This journal are designing measurement system and monitoring using software from LabVIEW. The method used to detect roll, pitch and yaw is combination from the measurement of gyroscope and accelerometer. The testing of the attitude sensing device by simulating the kinematics of an aircraft. The results shows that the attude sensing device are qualified for sensing tilt angle for $x$-axis (roll) with standard deviation $0,58^{\circ}$, sensing tilt angle for $y$-axis (pitch) with standard deviation $0.53^{\circ}$ and sensing tilit angle for $z$ (axis) with standar deviation $7,64^{\circ}$.
\end{abstract}

Kata Kunci : Gyroscope, Accelerometer, Inertial Measurement Unit, attitude 


\section{PENDAHULUAN}

Perkembangan teknologi khususnya di dunia penerbangan semakin pesat. Salah satu perkembangan di bidang tersebut adalah munculnya wahana terbang tanpa awak. Wahana terbang tersebut dikenal dengan istilah Unmanned Aerial Vehcile (UAV). Unmanned Aerial Verhicle adalah suatu wahana terbang tanpa awak yang dapat dapat terbang secara otomatis atau dapat dikendalikan dari jarak jauh.

Pengendalian otomatis dilakukan dengan metode closed-loop memerlukan umpan balik (feed-back). Umpan balik tersebut berupa informasi seperti kondisi, posisi, sikap (attitude) dan ketinggian yang didapat dari sensor - sensor yang ada pada wahana terbang. Tidak hanya berfungsi sebagai umpan balik (feed-back) informasi - informasi tersebut juga digunakan sebagai informasi pada sistem monitoring yang berfungsi untuk memantau dan mengendalikan wahana terbang dari jarak jauh. Pada penelitian ini membahas salah satu informasi yang digunakan sebagai umpan balik dan pada sistem monitoring pada wahana terbang. Informasi tersebut adalah sikap (attitude). Sikap (attitude) memberikan tiga informasi yaitu roll, pitch dan yaw. Roll, pitch dan yaw adalah suatu istilah pada wahana terbang untuk menginformasikan kemiringan sudut (tilt-angle) yang dialami wahana terbang.

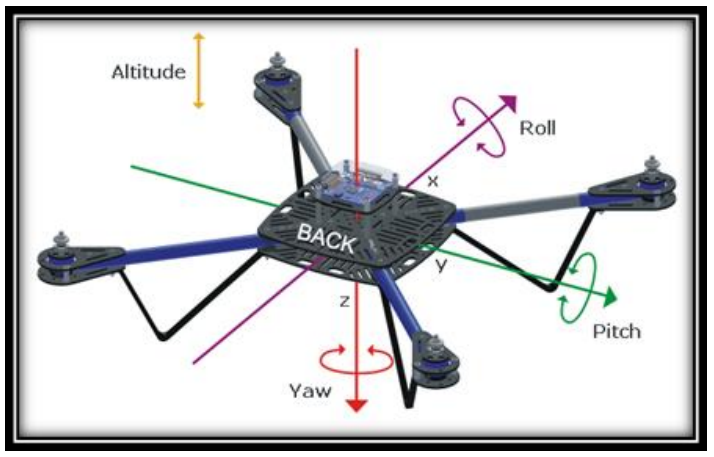

Gambar 1. Roll, pitch dan yaw

Informasi roll, pitch dan yaw akan digunakan untuk menjaga posisi wahana untuk tetap terbang dalam posisi stabil secara otomatis. Posisi stabil adalah wahana terbang tidak condong ke kiri, ke kanan, ke depan atau ke belakang. Informasi tersebut juga berfungsi untuk mengarahkan wahana terbang ke arah yang diinginkan serta sebagai salah satu informasi pada sistem monitoring sehingga wahana terbang dapat dipantau dan dikendalikan dari jarak jauh.

Untuk mendapatkan informasi sikap (attitude) diperlukan suatu sensor. Sensor tersebut adalah gyroscope. Gyroscope adalah suatu sensor yang digunakan untuk mengukur kecepatan angular ( $\%$ s) yang dialami oleh sensor. Kecepatan angular tersebut kemudian akan diproses menjadi informasi roll, pitch dan yaw yang akan menginformasikan tilt-angle pada wahana terbang. Hasil pengkuran menggunakan gyroscope diperoleh error di atas $5^{\circ}$, pada penelitian oleh M. Hasim dengan judul Pendeteksi sudut menggunakan sensor gyroscope disarankan untuk mengunakan metode pengkompensasian yang lain (M. Hasim As'Ari, 2009). Maka pada penelitian ini akan menggunakan accelerometer untuk mengkompensasi hasil pengukuran gyroscope. Hasil pengukuran gyrosocope yang digabungkan dengan accelerometer, diharapkan memperoleh nilai error di bawah $5^{\circ}$. Dari hasil pengukuran akan ditarik kesimpulan apakah spesifikasi dan hasil pengukuran dari penggabungan gyroscope dan accelerometer telah dapat mengakomodasi spesifikasi dari wahana terbang yang dimodelkan. 
Alat pendeteksi sikap (attitude) pada wahana terbang dirancang berdasarkan model wahana terbang kategori rotary wing dengan 4-motor pengerak (quad-rotor), sehingga spesifikasi dari alat pendeteksi sikap (attitude) harus dapat mengakomodasi aturan dari wahana terbang. Aturan dasar dari wahana terbang tersebut antara lain :

1. Wahana terbang (quad-rotor) dapat bergerak pada 3 sumbu. Sumbu tersebut adalah

a. Sumbu x (maju-mundur)

b. Sumbu y (kiri - kanan)

c. Sumbu z (naik - turun).

2. Kecepatan gerak pada wahana terbang diatur berdasarkan sudut kemiringan (tilt angle) pada arah gerak dengan 3 (tiga) kecepatan gerak. Kecepatan gerak tersebut adalah :
a. Gerak lambat $15^{\circ}$
b. Gerak cepat $30^{\circ}$
c. Gerak Sangat Cepat $45^{\circ}$

Berdasarkan pada latar belakang, maka tujuan penelitian penelitian ini adalah merancang sistem pengukuran dan monitoring untuk mengukur roll, pitch dan yaw pada wahana terbang dan menganalisis apakah sistem pengukuran dan monitoring ini sudah dapat mengakomodasi spesifikasi wahana terbang yang dimodelkan.

Sistem penggukuran dan monitoring pada penelitian ini direalisasikan berdasarkan 3 (tiga) perangkat keras. Perangkat keras tersebut adalah Alat ukur inersial yang terdiri dari accelerometer dan gyroscope, mikrokontroler Arduino Mega ADK serta PC (personal Computer). Tampilan yang digunakan untuk menampilkan output dari sistem pengukuran/pendeteksi sikap (attitude) menggunakan program LabVIEW versi 2013.

\section{METODOLOGI}

\subsection{Attitude and Heading Refrence System}

Attitude and Heading Refrence System (AHRS) adalah suatu model sistem referensi navigasi yang digunakan pada bidang penerbangan. Sistem referensi ini digunakan sebagai alternatif untuk memperoleh 4 informasi dasar yaitu kecepatan (airspeed), sikap (attitude), ketingian (altitude) dan arah terbang (heading). Dikatakan sebagai alternatif karena pada umumnya untuk memperoleh informasi dasar seperti yang telah disebutkan sebelumnya menggunakan sensor - sensor yang berbeda untuk tiap - tiap informasi tersebut. Seperti yang terlihat pada Gambar 2 dengan mengunakan 3 sensor yaitu accelerometer, gyroscope dan compas dapat diperoleh 4 informasi dasar melalui proses matematis.

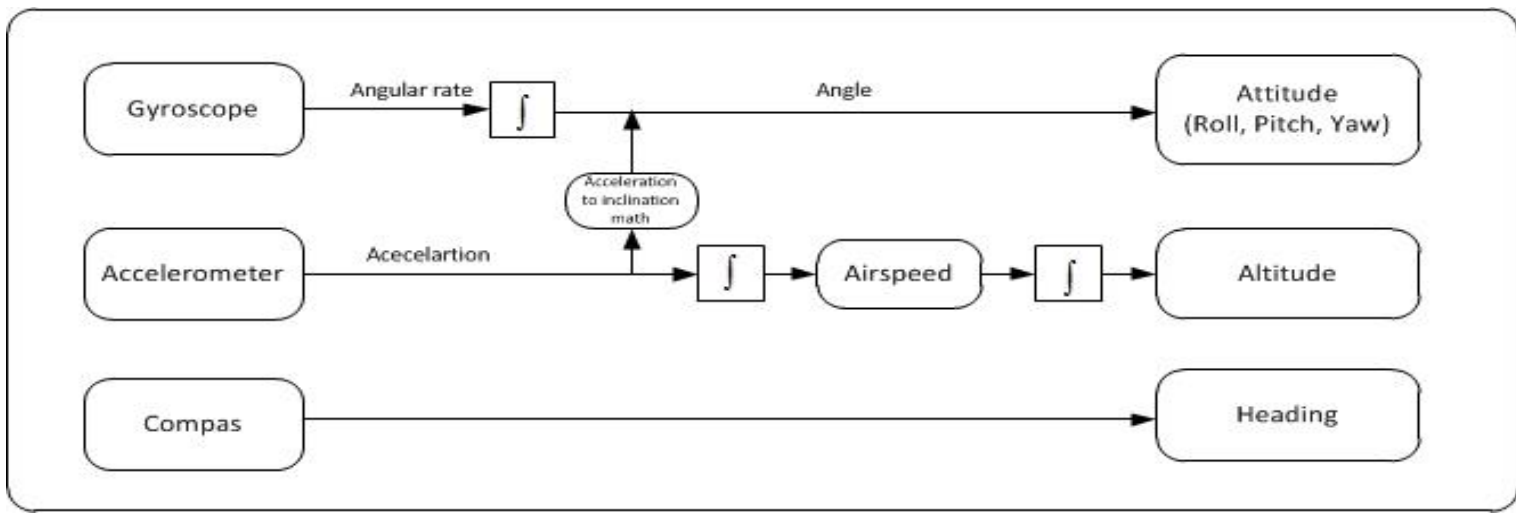

Gambar 2. Attitude And Heading Reference System 


\subsection{Accelerometer sebagai Pendeteksi Kemiringan}

Accelerometer dapat digunakan sebagai pendeteksi kemiringan sudut (tilt-angle) dengan melakukan perhitungan trigonometri. Perhitungan ini hanya dapat digunakan untuk menentukan kemiringan sudut (tilt-ang/e) pada sumbu (x) roll dan sumbu (y) pitch. Gambar 3 memperlihatkan sumbu - sumbu pada alat ukur inersial MPU-6050.

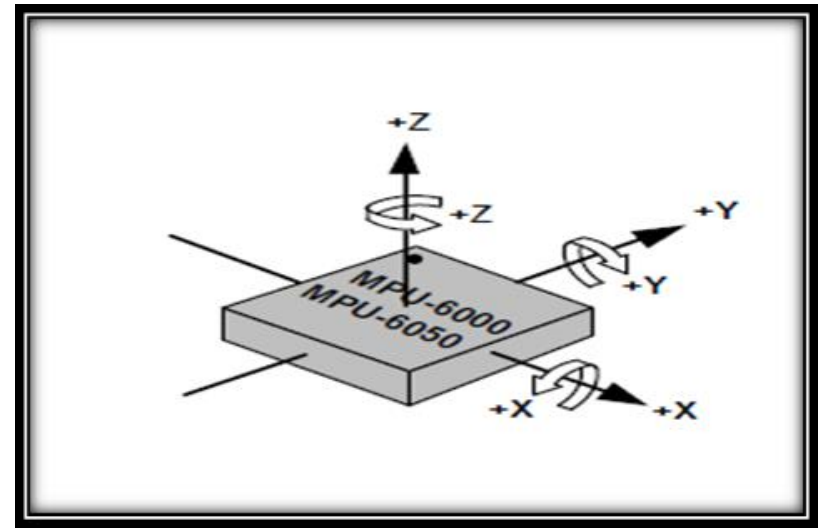

Gambar 3. Sumbu - sumbu pada alat ukur inesial MPU-6050

Untuk menghitung kemiringan sudut (tilt-angle) pada sumbu x (rol/) dan sumbu y (pitch) pada accelerometer dengan 3-derajat kebebasan (3-DoF) dilakukan dengan menyederhanakan sistem koordinat 3-dimensi $(x, y, z)$ menjadi 2-dimensi. Penyederhanaan 2dimensi tersebut yaitu menyederhanakan vektor referensi dan vektor ukur. Pada persamaan (1) dan (2) $A_{x}$ adalah hasil penggukuran accelerometer pada sumbu $x, A_{y}$ adalah hasil penggukuran accelerometer pada sumbu y dan $A_{z}$ adalah hasil penggukuran accelerometer pada sumbu $z$.

Roll adalah kemiringan sudut (tilt-angle) yang terjadi pada sumbu y relatif terhadap permukaan tanah/darat. Vektor referensi pada sudut roll adalah permukaan tanah yaitu magnitude dari vektor $\mathrm{x}$ dan vektor $\mathrm{z}$ sedangkat vektor ukur adalah vektor $\mathrm{y}$, sehingga dengan penulisan sederhana dapat dituliskan sebagai berikut :

$$
\operatorname{Roll}(\theta)=\tan ^{-1} \frac{A_{y}}{\sqrt{A_{x}^{2}+A_{z}^{2}}}
$$

Pitch adalah kemiringan sudut (tilt-angle) yang terjadi pada sumbu $\mathrm{x}$ relatif terhadap permukaan tanah/darat. Vektor referensi pada sudut pitch adalah permukaan tanah yaitu magnitude dari vektor $\mathrm{y}$ dan vektor $\mathrm{z}$ sedangkat vektor ukur adalah vektor $\mathrm{x}$, sehingga dengan penulisan sederhana dapat dituliskan sebagai berikut :

$$
\operatorname{Pitch}(\theta)=\tan ^{-1} \frac{A_{x}}{\sqrt{A_{y}{ }^{2}+A_{z}{ }^{2}}}
$$

Yaw tidak dapat ditentukan oleh accelerometer karena yaw tidak mengunakan titik referensi untuk melakukan pengukuran. Untuk mengukur kemiringan sudut (tilt-angle) yaw maka harus menggunakan gyroscope atau compass. 


\subsection{Gyroscope Sebagai Pendeteksi Kemiringan}

Pembacaan kemiringan sudut (tilt-angle) dari gyroscope dilakukan dengan mengintegralkan hasil pengukuran gyroscope. $\omega(t)$ merupakan fungsi waktu dari hasil pembacaan gyroscope pada sumbu $x$ (rol/), sumbu y (pitch) dan sumbu z (yaw) yang memiliki satuan kecepetan sudut $(\% / \mathrm{s}), \theta(t)$ merupakan fungsi waktu dari nilai kemiringan sudut (tilt-angle) sudut dari pembacaan gyroscope pada sumbu x (rol/), sumbu y (pitch) dan sumbu z (yaw) yang memiliki satuan derajat $\left({ }^{\circ}\right)$. Persamaan ini dapat dituliskan sebagai berikut :

$$
\begin{aligned}
& \theta(t)=\int_{t-1}^{t} \omega(t) d t \\
& \frac{d \theta(t)}{d t}=\omega(t)
\end{aligned}
$$

Bentuk diskrit dari persamaan 4 dapat dituliskan sebagai berikut :

$$
\begin{aligned}
& \frac{\theta_{t+1}-\theta_{t}}{\Delta t}=\omega(t) \\
& \theta_{t+1}=\omega_{t} \Delta t+\theta_{t}
\end{aligned}
$$

\subsection{Gambaran Umum Sistem}

Berdasarkan aturan dasar dari wahana terabang (quad-rotor), maka dapat diturunkan spesifikasi dari alat pendeteksi sikap. Spesifikasi alat pendeteksi sikap tersebut sebagai berikut :

1. Alat pendeteksi sikap dapat mendeteksi pergeseran sudut pada sumbu gerak. Sumbu tersebut adalah :
a. Sumbu $x$ (roll)
b. Sumbu y (pitch)
c. Sumbu z (Yaw)

2. Alat pendeteksi sikap harus dapat mengukur dan membedakan sudut kemiringan (tilt angle) pada sudut - sudut $0^{\circ}, 15^{\circ}, 30^{\circ}$ dan $45^{\circ}$. Sehingga skala pengukuran adalah per $15^{\circ}$, tetapi untuk memperoleh hasil yang lebih baik maka skala pengukuran akan dilakukan per $5^{\circ}$.

Secara umum sistem yang dirancang memiliki 3 sub-sistem yaitu bagian input yang diwakilkan dengan blok sub-sistem alat ukur inersial, proses yang diwakilkan pada blok subsistem unit kendali dan output yang diwakilkan pada blok sub-sistem unit display.

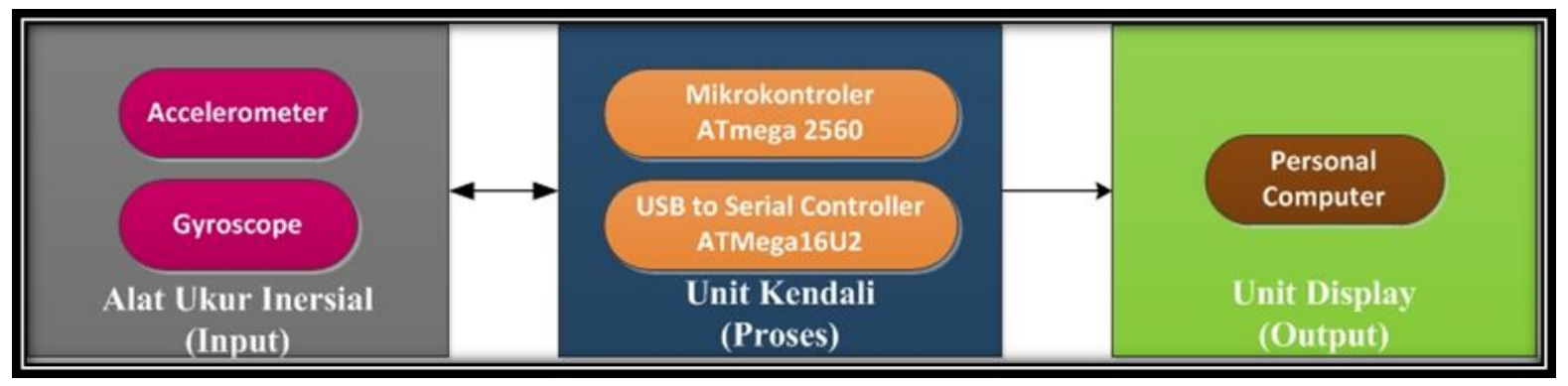

Gambar 4. Blok diagram sistem secara umum

Sistem yang dirancang seperti yang terlihat pada Gambar 4 pada penelitian ini memiliki spesifikasi serta penjelasan singkat sebagai berikut : 


\section{a. Alat ukur inersial}

Alat ukur inersial pada sistem adalah alat ukur inersial MPU-6050 dari invensense. Alat ukur inersial ini memiliki 2 jenis sensor yaitu accelerometer dan gyroscope. Alat ukur inersial tersebut berfungsi untuk membaca nilai akselerasi yang dialami oleh accelerometer dan nilai kecepatan putar sudut yang dialami oleh gyroscope.

b. Unit Kendali

Unit kendali pada sistem ini terdiri dari 2 buah mikrokontroler, yaitu ATmega2560 dan Atmega16U2. Fungsi - fungsi dari unit kendali pada sistem ini adalah sebagai berikut :

- Berfungsi untuk membaca hasil pengukuran dari sensor serta pengaturan sensor mengunakan protokol komunikasi $\mathrm{I}^{2} \mathrm{C}$.

- Berfungsi sebagai pengolah perhitungan matematis yang digunakan untuk mengkonversi hasil pengukuran sensor gyroscope yang berupa kecepatan sudut $(\%)$ dan acceleromter yang berupa (a) menjadi nilai pergeseran sudut pada sumbu longitudinal, lateral dan vertikal.

- Berfungsi sebagai media pentransmisian data hasil pengukuran yang telah diolah melalui protokol komunikasi serial (RS-232).

c. Unit Display

Personal computer digunakan sebagai display dari hasil pengukuran oleh sensor - sensor pada alat ukur inersial yang telah diolah pada mikrokontroler dengan mengunakan program LabVIEW versi 2013. Personal computer yang digunakan memiliki spesifikasi sebagai berikut :

- PC mengunakan sistem operasi windows 7 32-bit

- Program yang digunakan sebagai display adalah LabVIEW versi 2013.

\subsection{Perancangan Perangkat Keras}

Pada penelitian ini sistem dirancang mengunakan 3 (tiga) perangkat keras yaitu alat ukur inersial MPU-6050, Mikrokontroler Arduino Mega ADK dan Personal Computer seperti yang terlihat pada Gambar 5.

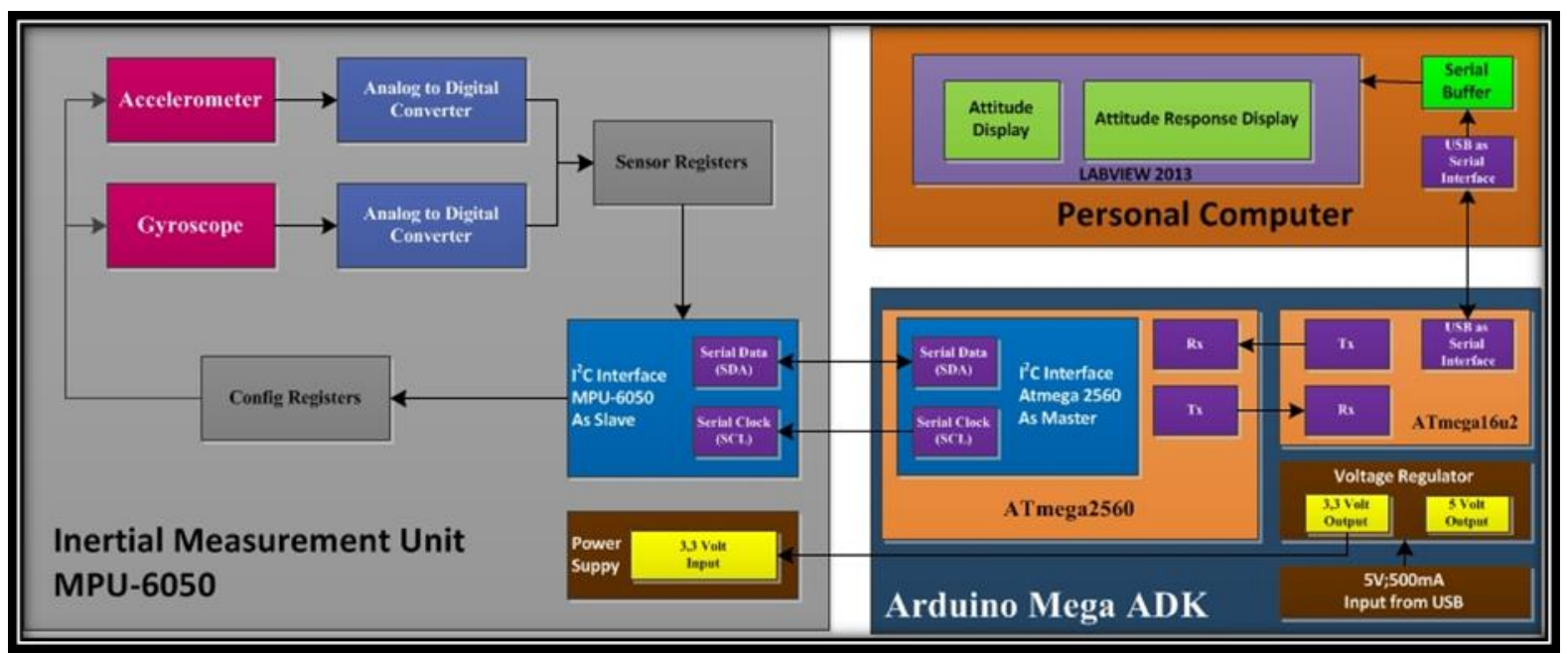

Gambar 5. Diagram Blok Perangkat Keras 
Pemaparan lebih lanjut mengenai perancangan perangkat keras adalah sebagai berikut :

a. Alat Ukur Inersial MPU-6050

Alat ukur inersial MPU-6050 dari invensense adalah alat ukur inersial yang terdiri dari accelerometer dan gyroscope. Alat ukur ini mengunakan catu daya sebesar 3,3 Volt DC. Catu daya tersebut diperoleh dari catu daya yang disediakan oleh Mikrokontroler Arduino Mega ADK. Protokol komunikasi yang digunakan untuk membaca hasil pengukuran dari sensor - sensor serta pengaturan konfigurasi sensor - sensor pada alat ukur inersial menggunakan portokol komunikasi $\mathrm{I}^{2} \mathrm{C}$.

Sensor - sensor pada alat ukur inersial MPU-6050 dapat dikonfigurasi. Konfigurasi konfigurasi tersebut antara lain mengatur kecepatan cuplik (sampling rate) dan skala penuh pengukuran sensor (full scale range). Pengaturan tersebut dilakukan dengan cara mengubah nilai register pada alamat - alamat tertentu.

Setelah melakukan pengaturan pada config register mengenai parameter - parameter sensor maka spesifikasi akhir dari sensor adalah sebagai berikut :

\section{i. Accelerometer}

- waktu cuplik (sampling rate) sebesar $1 \mathrm{kHz}$.

- Skala penuh pengukuran sensor (full scale range) sebesar $\pm 2 \mathrm{~g}\left(\mathrm{~m} / \mathrm{s}^{2}\right)$.

ii. Gyroscope

- Waktu cuplik (sampling rate) sebesar $8 \mathrm{kHz}$.

- Skala penuh pengukuran sensor (full scale range) sebesar $\pm 250 \%$.

b. Mikrokontroler Arduino Mega ADK

Mikrokontroler Arduino Mega ADK adalah suatu mikrokontroler berbasis Atmega2560. Atmega2560 adalah mikrontroler dengan arsitektur 8-bit RISC AVR. Mikrokontoler Arduino mega ADK memiliki software intergrated development enviroment (IDE) khusus yang digunakan untuk memprogram mikrokontoler menggunakan bahasa pemrograman $\mathrm{C} / \mathrm{C}++$.

\section{c. Personal Computer}

Personal computer digunakan sebagai display hasil pengukuran dari sensor - sensor pada sistem. Komunikasi yang digunakan antara mikrokontroler dengan PC mengunakan komunikasi serial RS-232. Spesifikasi dari PC tersebut adalah sebagai berikut :
i. Processor Intel Core i3 2,73 Ghz
ii. RAM DDR3 1GB
iii. Operating System Windows 7 32-bit
iv. LabVIEW 2013 32-bit

\subsection{Perancangan Perangkat Lunak}

Pada sistem ini perancangan perangkat lunak dilakukan pada unit display yaitu personal computer dan unit kontrol yaitu mikrokontroler. Perancangan perangkat lunak pada personal computer menggunakan aplikasi LabView 2013 yang akan digunakan sebagai display dari hasil pengukuran. Perancangan perangkat lunak pada mikrokontroler menggunakan bahasa pemrograman $\mathrm{C}++$ menggunakan aplikasi IDE (Integrated development enviroment) dari Arduino. Diagram alur dari proses - proses tersebut dapat dilihat pada Gambar 6.

Secara umum terdapat 4 (empat) proses komputasi yang dilakukan pada sistem ini. Proses proses tersebut adalah : 
1. initiating system melakukan inisiasi protokol komunikasi, konfigurasi sensor dan menentukan faktor kalibrasi.

2. Reading sensor measurement adalah membaca data hasil pengukuran gyroscope dan accelerometer.

3. Processing sensor measurement into attitude adalah melakukan perhitungan matematis untuk mendapatkan informasi attitude (Roll, pitch dan yaw).

4. Display attitude adalah menampilkan informasi attitude (Roll, pitch dan yaw) pada personal computer.

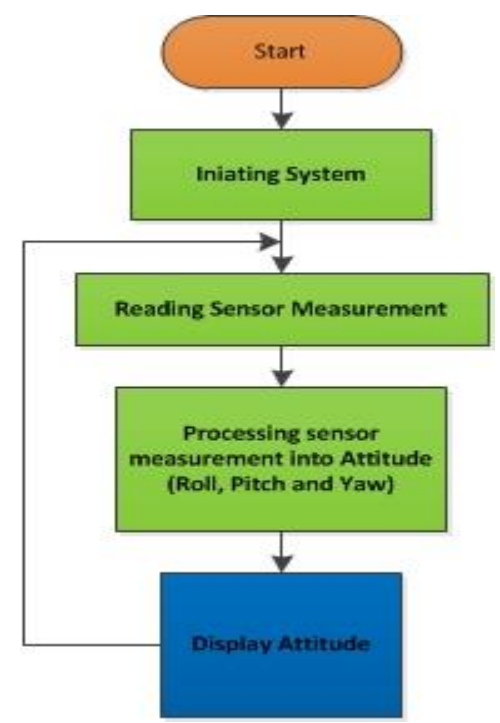

Gambar 6. Flowchart program secara umum

Proses yang pertama hingga proses yang ketiga terjadi di dalam mikrokontroler Arduino Mega ADK (ATmega 2560) sedangkan proses yang ke-empat terjadi pada personal computer.

\subsection{Realisasi perangkat keras}

Realisasi perangkat keras dilakukan di atas project board. Hubungan anatara mikrokontroler Arduino Mega ADK dilakukan dengan menggunakan jumper. Realisasi perangkat keras dapat dilihat pada Gambar 7. Alat ukur inersial MPU-6050 terletak pada ujung kanan project board seperti yang terlihat pada Gambar 7. Sedangkan mikrokontroler Arduino Mega ADK terletak di sebelah kiri project board. Sumbu $X$ terletak pararel dengan project board dan sumbu $Y$ terletak bersilangan dengan project board seperti yang terlihat pada Gambar 3.4. Sedangkan sumbu Z terletak pararel dengan arah pengambilan Gambar 7 (vertical terhadap project board).

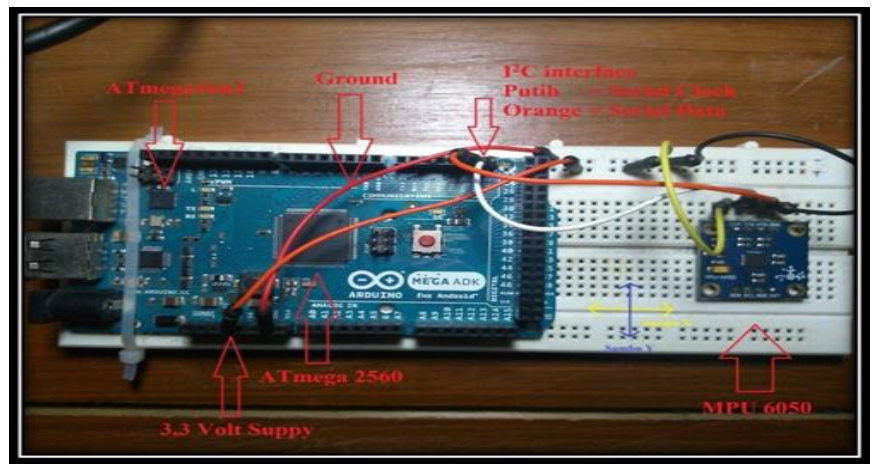

Gambar 7. Realisasi Perangkat Keras 


\subsection{Realisasi perangakt Lunak}

Realisasi perangkat lunak dilakukan pada software LabVIEW versi 2013. Software LabVIEW 2013 berfungsi untuk menampilkan hasil pengukuran dari alat ukur inersial. Pada gambar 8 dapat dilihat tampilan dari sistem pengukuran dan monitoring alat pendeteksi sikap (attitude). Pemrograman LabVIEW dilakukan dengan mengkonfigurasi block - block yang merepesentasikan suatu fungsi.

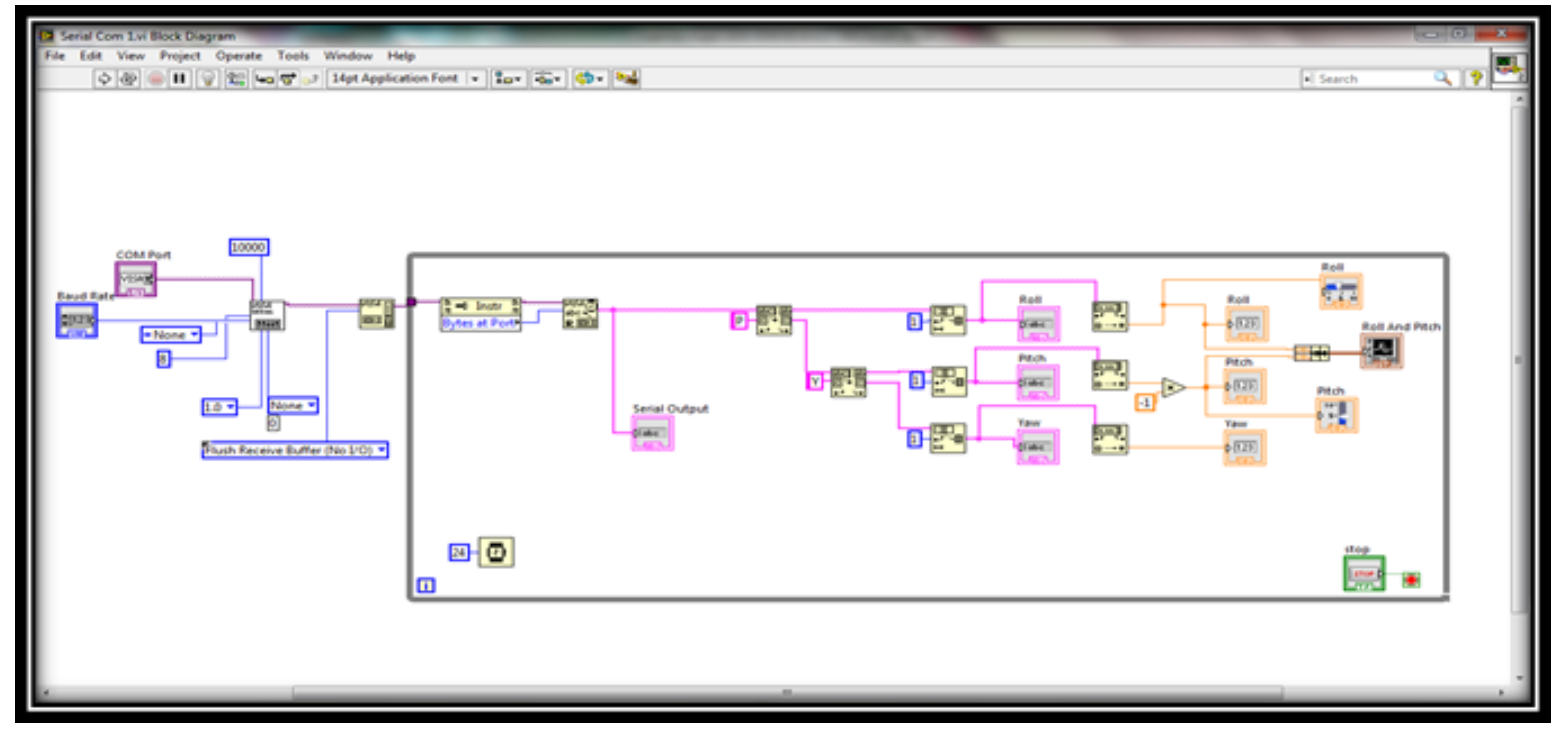

Gambar 8. Blok Program LabVIEW

Hasil pengukuran yang berupa pitch, roll dan yaw disajikan dalam 3 (tiga) format data seperti yang terlihat pada Gambar 9. Format pertama adalah indikator yang menyajikan data roll, pitch dan yaw. Format kedua adalah grafik digunakan untuk melihat respon dari pengukuran rol/ dan pitch. Format ketiga disajikan dalam bentuk bar, vertical bar menyajikan data pitch dan horizontal bar menyajikan data roll. Informasi yang ditampilan pada software LabVIEW memiliki satuan derajat $\left({ }^{\circ}\right)$.

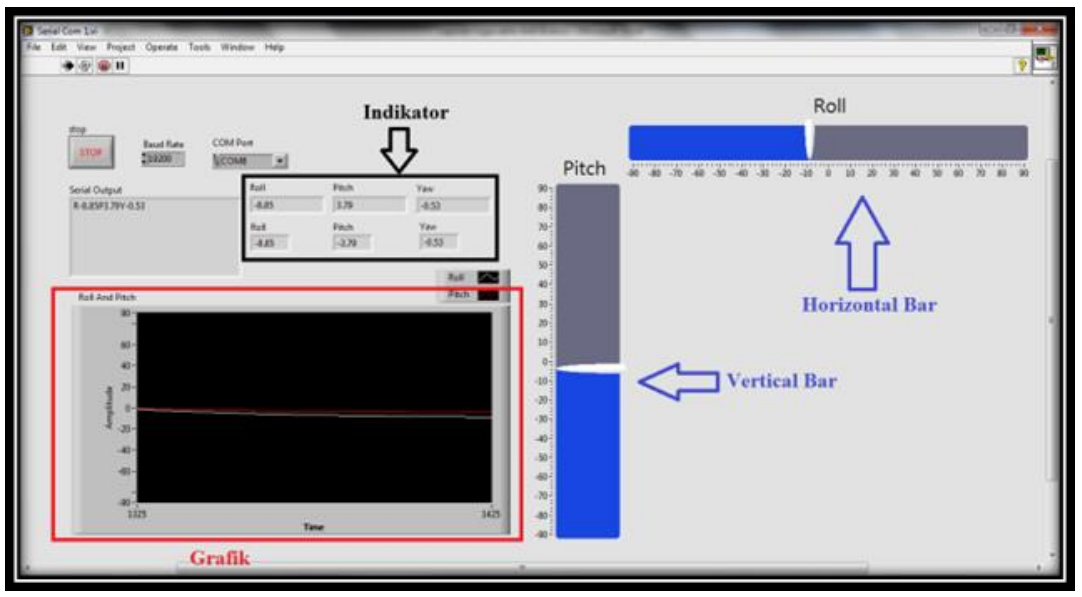

Gambar 9. LabVIEW Display

Pengaturan program dilakukan dengan mengatur nilai baud rate sebesar 19200 dan pengaturan port komunikasi serial sebelum menjalankan program ini. Pengisian buad rate dilakukan secara manual pada kolom Baud Rate dan port komunikasi dengan membuka combo box pada kolom COMM Port. 


\section{PENGUJIAN DAN ANALISIS}

\subsection{Metode Pengujian}

Pengujian dari alat pendeteksi sikap (attitude) menggunakan alat ukur inersial dilakukan dengan cara menyimulasikan kinematika dari pergerakan wahana terbang. Kinematika pergerakan tersebut adalah rotasi pada sumbu x (rol/), rotasi pada sumbu y (pitch) dan rotasi pada sumbu $z$ (yaw). Rotasi pada tiap sumbu dilakukan searah dengan jarum jam (sumbu positif) dan berlawanan dengan arah jarum jam (sumbu negatif). Rotasi pada tiap tiap sumbu diukur dalam satuan derajat $\left({ }^{\circ}\right)$.

Nilai pengukuran rotasi dimulai dari $0^{\circ}$ hingga $70^{\circ}$. Nilai tersebut dipilih untuk mensimulasikan kinematika wahana terbang tanpa awak kategori rotary wing dengan 4-rotor penggerak (quad-rotor). Pengukuran dilakukan sebanyak 5 (lima) kali yang dilakukan secara berulang pada tiap - tiap sumbu rotasi. Skala pengukuran rotasi adalah sebesar $5^{\circ}$ dan $10^{\circ}$. Pengaturan rotasi dari $0^{\circ}$ hingga $70^{\circ}$ dilakukan secara manual dengan cara menyimulasikan alat pendeteksi sikap terhadap nilai kemiringan yang diukur menggunakan busur derajat.

Pengukuran dilakukan menggunakan dua alat simulasi yang berbeda. Penjelasan mengenai alat tersebut adalah sebagai berikut :

\section{a. Alat penyimulasi rotasi sumbu $x$ (roll) dan sumbu y (pitch)}

Kinematika pergerakan yang dapat disimulasikan pada alat ini adalah rotasi pada sumbu $x$ (roll) dan sumbu y (pitch). Alat simulasi ini dapat dilihat pada Gambar 10. Pengukuran rotasi sumbu x (roll) dan sumbu y (pitch) dilakukan pada bidang yang datar. Pengukuran yang dilakukan pada bidang yang datar agar tidak terjadi pergeseran sumbu ukur akibat adanya kemiringan pada bidang ukur. Untuk memastikan bahwa bidang ukur merupakan bidang datar maka digunakan waterpass. Apabila indikator pada waterpass menunjukan kemiringan pada bidang ukur maka dilakukan koreksi dengan mengeser busur derajat (papan putih) hingga indikator pada waterpass menunjukan kondisi datar.

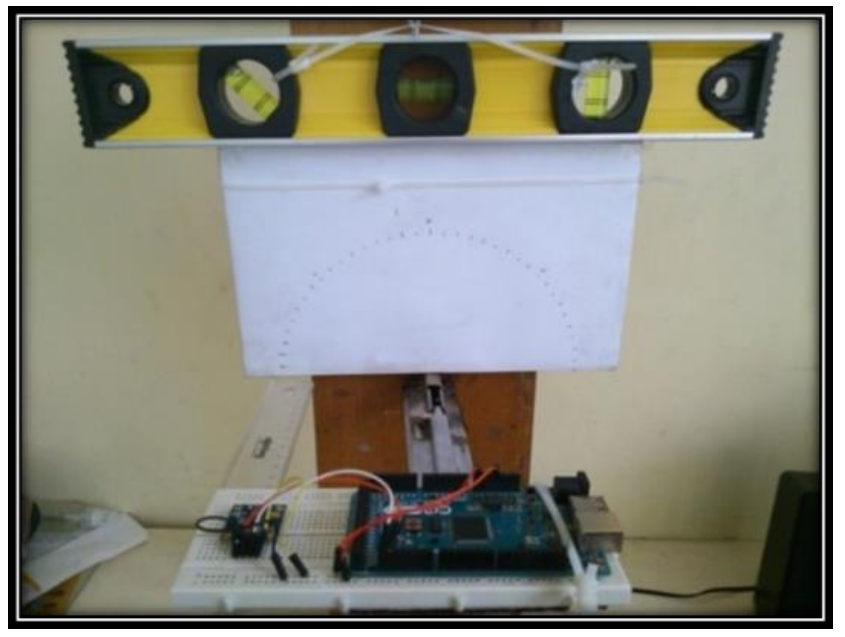

Gambar 10. Alat simulasi rolldan pitch

Apabila indikator pada waterpass telah menunjukan posisi datar maka pengukuran dapat mulai dilakukan. Pengukuran dilakukan dengan mengesser posisi dari alat ukur inersial searah jarum jam dan berlawanan arah jarum jam. Pergeseran searah jarum jam untuk mendapatkan nilai rotasi pada sumbu positif dan pergeseran berlawanan dengan arah jarum jam untuk mendapatkan nilai rotasi pada sumbu negatif. Kedua pergeseran tersebut dimulai dari $0^{\circ}$ hingga $70^{\circ}$ dengan skala $5^{\circ}$ dan $10^{\circ}$. Dilakukan penggulangan 
pengukuran sebanyak 5 (lima) kali pada tiap sumbu rotasi. Pembacaan nilai yang terukur dilakukan melalui software LabVIEW pada personal computer. Nilai yang terukur kemudian akan dibandingkan dengan nilai sebenarnya. Nilai sebenarnya diperoleh dari pengukuran menggunakan busur derajat.

\section{b. Alat penyimulasi rotasi sumbu z (yaw)}

Kinematika pergerakan yang dapat disimulasikan pada alat ini adalah rotasi pada sumbu $\mathrm{z}$ (yaw). Alat simulasi ini dapat dilihat pada Gambar 11. Pada alat simulasi yang terlihat pada Gambar 11 pengukuran dilakukan dengan mengesser posisi dari alat ukur inersial searah jarum jam dan berlawanan jarum jam. Pergeseran searah jarum jam untuk mendapatkan nilai rotasi pada sumbu positif dan pergeseran berlawanan dengan arah jarum jam untuk mendapatkan nilai rotasi pada sumbu negatif.

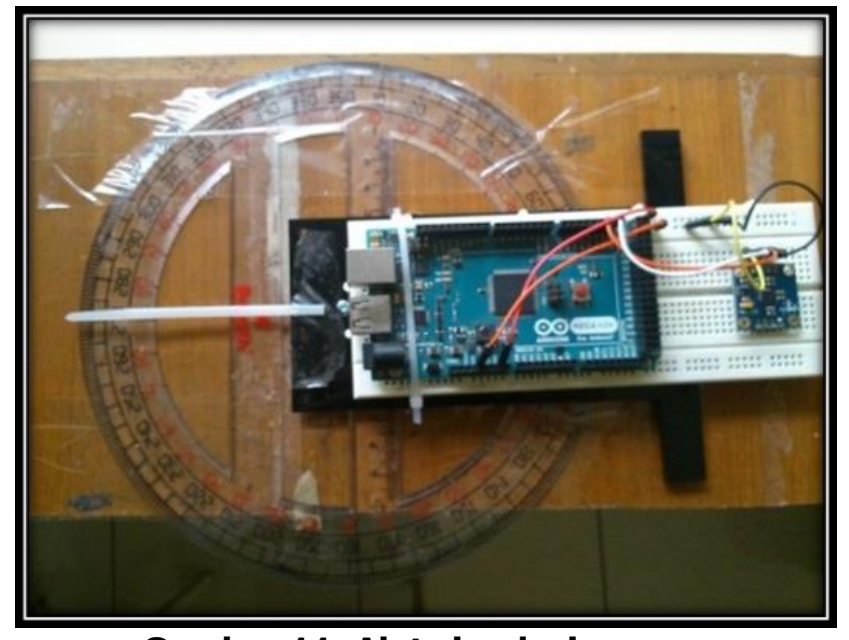

Gambar 11. Alat simulasi yaw

Kedua pergeseran tersebut dimulai dari $0^{\circ}$ hingga $70^{\circ}$ dengan skala $5^{\circ}$ dan $10^{\circ}$. Dilakukan penggulangan pengukuran sebanyak 5 (lima) kali pada tiap sumbu rotasi. Pembacaan nilai yang terukur dilakukan melalui software LabVIEW pada personal computer. Nilai yang terukur kemudian akan dibandingkan dengan nilai sebenarnya. Nilai sebenarnya diperoleh dari pengukuran menggunakan busur derajat.

\subsection{Hasil Pengujian}

Hasil pengujian dari alat pendeteksi sikap (attitude) menggunakan alat ukur inersial akan disajikan dalam 3 (tiga) kategori. Kategori tersebut adalah rotasi pada sumbu x (rol/), sumbu y (pitch) dan sumbu z (yaw). Pada tiap kategori akan dibagi menjadi 2 kategori berdasarkan arah pergerakanya. Arah pergerakan tersebut adalah rotasi searah jarum jam (rotasi pada sumbu positif) dan berlawanan dengan arah jarum jam (rotasi pada sumbu negatif). Pengujian dilakukan berulang sebanyak 5 (lima) kali pengulangan. Tujuan dari penggulangan untuk mendapatkan nilai rata - rata yang terbaik untuk digunakan mencari nilai simpangan rata - rata (standard deviasi). Persamaan yang digunakan untuk mencari standard deviasi adalah persamaan 7 .

$$
\pm \Delta x=\sqrt{\frac{\left(\sum x_{i}-\sum \bar{x}\right)^{2}}{n-1}}
$$


Simpangan rata - rata (standar deviasi) adalah suatu simpangan / error yang terukur oleh alat pendeteksi sikap. Simpangan / error tersebut merepresentasikan nilai akurasi suatu sensor. Sehingga semakin kecil nilai simpangan rata - rata maka semakin dekat hasil pengukuran dengan nilai sebenarnya sehingga semakin akurat hasil pengukuran yang terukur. Sebaliknya, semakin besar nilai simpangan rata - rata maka semakin tidak akurat hasil pengukuran yang terukur.

\section{a. Rotasi pada sumbu $x$ (roll)}

Rotasi pada sumbu $x$ (rol/) searah jarum jam merupakan rotasi pada sumbu positif atau pergerakan wahana terbang adalah miring ke arah kanan. Sedangkan rotasi pada sumbu $x$ (rol) berlawanan dengan jarum jam merupakan rotasi pada sumbu negatif atau pergerakan wahana terbang adalah miring ke arah kiri. Data hasil pengukuran rotasi adalah sebagai berikut :

\section{a.1 Rotasi pada sumbu x (roll) positif}

Tabel 1. Tabel rotasi pada sumbu $x$ (roll) positif skala pengukuran $\mathbf{5}^{0}$

\begin{tabular}{|c|c|c|c|c|c|c|c|c|}
\hline \multirow{3}{*}{ No } & \multirow{3}{*}{$\begin{array}{c}\text { Nilai } \\
\text { Sebenarnya }\end{array}$} & \multicolumn{7}{|c|}{ Hasil Pengukuran Skala Pengukur $5^{\circ}$ Sumbu Positif } \\
\hline & & \multicolumn{5}{|c|}{ Pengukuran Ke-n } & \multicolumn{2}{|c|}{ Rata Rata } \\
\hline & & Ke-1 & ke-2 & ke-3 & $\mathrm{Ke}-4$ & Ke-5 & Pengukuran & simpangan \\
\hline 1 & 0 & 0.5 & 0.6 & 0.7 & 0.2 & 0.4 & 0.48 & 0.19 \\
\hline 2 & 5 & 4.8 & 4.7 & 5.1 & 5.4 & 4.6 & 4.92 & 0.33 \\
\hline 3 & 10 & 10.8 & 10 & 10.8 & 10.9 & 10.7 & 10.64 & 0.36 \\
\hline 4 & 15 & 16.6 & 15.9 & 15.8 & 16.5 & 14.8 & 15.92 & 0.72 \\
\hline 5 & 20 & 20.5 & 21.1 & 21.9 & 21.3 & 19.6 & 20.88 & 0.87 \\
\hline 6 & 25 & 25.8 & 25.9 & 26.5 & 26.4 & 24.6 & 25.84 & 0.76 \\
\hline 7 & 30 & 31.9 & 30.9 & 31.5 & 31.5 & 30.3 & 31.22 & 0.63 \\
\hline 8 & 35 & 36.8 & 36.8 & 36.2 & 36.4 & 35.7 & 36.38 & 0.46 \\
\hline 9 & 40 & 42.3 & 41.7 & 41.4 & 41.9 & 39.7 & 41.40 & 1.00 \\
\hline 10 & 45 & 45.9 & 46.3 & 45.9 & 45.7 & 44.2 & 45.60 & 0.81 \\
\hline 11 & 50 & 50.5 & 50.7 & 50.8 & 50.2 & 50.1 & 50.46 & 0.30 \\
\hline 12 & 55 & 55.7 & 55.6 & 56.4 & 54.7 & 54.7 & 55.42 & 0.73 \\
\hline 13 & 60 & 60.5 & 60.4 & 61.2 & 59.9 & 59.5 & 60.30 & 0.64 \\
\hline 14 & 65 & 65.3 & 64.9 & 65.5 & 64.1 & 64.4 & 64.84 & 0.59 \\
\hline 15 & 70 & 70.4 & 69.8 & 69.8 & 68.9 & 69.4 & 69.66 & 0.55 \\
\hline \multicolumn{8}{|c|}{ gan Rata - Rata } & 0.60 \\
\hline
\end{tabular}

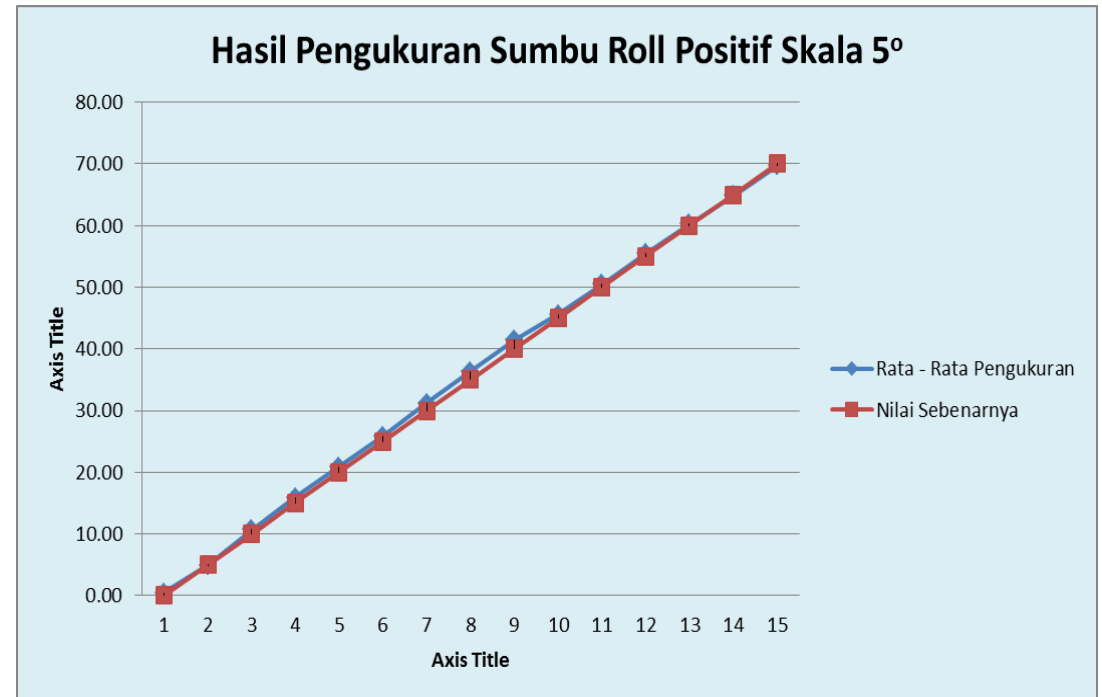

Gambar 12. Grafik rotasi pada sumbu x (rol/) positif skala pengukuran $5^{0}$ 
Hasil pengukuran rotasi pada sumbu x (rol/) positif pada skala $5^{\circ}$ diperoleh simpangan rata rata sebesar $0,60^{\circ}$ terhadap nilai sebenarnya. Pada Gambar 12 dapat dilihat bahwa hasil pengukuran sudah mendekati nilai sebenarnya dengan simpangan terbesar pada pengkuran $40^{\circ}$ dengan simpangan sebesar $1^{\circ}$.

Tabel 2. Tabel rotasi pada sumbu $x$ (rol/) positif skala pengukuran $10^{\circ}$

\begin{tabular}{|c|c|c|c|c|c|c|c|c|}
\hline \multirow{2}{*}{ No No } & \multirow{2}{*}{$\begin{array}{c}\text { Nilai } \\
\text { Sebenarnya }\end{array}$} & \multicolumn{6}{|c|}{ Pasil Pengukuran Skala Pengukur $10^{\circ}$ Sumbu Positif } \\
\cline { 3 - 9 } & & Ke-1 & ke-2 & ke-3 & Ke-4 & Ke-5 & Pengukuran & simpangan \\
\hline 1 & 0 & 0.2 & 0.3 & 0.4 & 0.2 & 0.7 & 0.36 & 0.21 \\
\hline 2 & 10 & 10.9 & 10.7 & 11.2 & 10.9 & 10.2 & 10.78 & 0.37 \\
\hline 3 & 20 & 20.9 & 21.6 & 21.5 & 20.9 & 20.5 & 21.08 & 0.46 \\
\hline 4 & 30 & 31.2 & 31.7 & 31.4 & 31.2 & 30.4 & 31.18 & 0.48 \\
\hline 5 & 40 & 41.9 & 41.5 & 41.1 & 41.2 & 40.4 & 41.22 & 0.55 \\
\hline 6 & 50 & 51.2 & 50.9 & 50.6 & 50 & 49.5 & 50.44 & 0.69 \\
\hline 7 & 60 & 60.6 & 60.4 & 60.3 & 59.9 & 59.5 & 60.14 & 0.44 \\
\hline 8 & 70 & 70.3 & 69.7 & 69.3 & 69 & 68.6 & 69.38 & 0.65 \\
\hline \multicolumn{8}{|c|}{ Simpangan Rata - Rata } \\
\hline
\end{tabular}

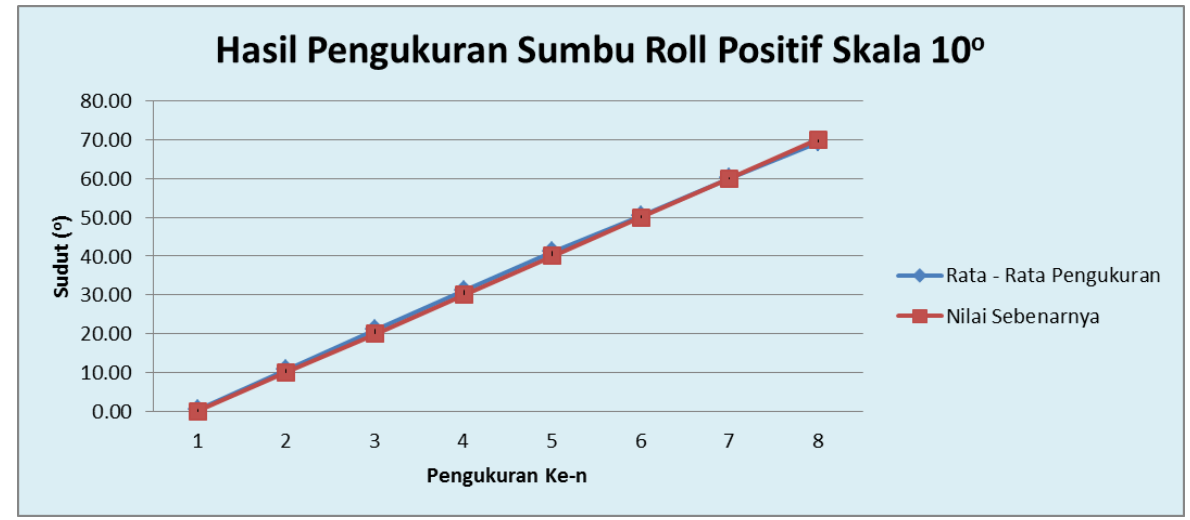

Gambar 13. Grafik rotasi pada sumbu $x$ (roll) positif skala pengukuran $10^{\circ}$

Hasil pengukuran rotasi pada sumbu x (rol/) positif pada skala $10^{\circ}$ diperoleh simpangan rata - rata sebesar $0,48^{\circ}$ terhadap nilai sebenarnya. Pada Gambar 13 dapat dilihat bahwa hasil pengukuran sudah mendekati nilai sebenarnya dengan simpangan terbesar pada pengkuran $50^{\circ}$ dengan simpangan sebesar $0,69^{\circ}$.

\section{A.2 Rotasi pada sumbu x (roll) negatif}

Tabel 3. Tabel rotasi pada sumbu $x$ (rol/) negatif skala pengukuran $\mathbf{5}^{0}$

\begin{tabular}{|c|c|c|c|c|c|c|c|c|}
\hline \multirow{3}{*}{ No } & \multirow{3}{*}{$\begin{array}{c}\text { Nilai } \\
\text { Sebenarnya }\end{array}$} & \multicolumn{7}{|c|}{ Hasil Pengukuran Skala Pengukur $5^{\circ}$ Sumbu Negatif } \\
\hline & & \multicolumn{5}{|c|}{\begin{tabular}{|l|} 
Pengukuran Ke-n \\
\end{tabular}} & \multicolumn{2}{|c|}{ Rata Rata } \\
\hline & & $\mathrm{Ke}-1$ & ke-2 & ke-3 & $\mathrm{Ke}-4$ & $\mathrm{Ke}-5$ & Pengukuran & simpangan \\
\hline 1 & 0 & 0.4 & 0.6 & 0.5 & 0.4 & 0.4 & 0.46 & 0.09 \\
\hline 2 & 5 & 5.3 & 5.7 & 6.3 & 5.2 & 4.7 & 5.44 & 0.60 \\
\hline 3 & 10 & 11.3 & 11.4 & 10.3 & 10.4 & 9.3 & 10.54 & 0.86 \\
\hline 4 & 15 & 16.6 & 16.3 & 15.3 & 15.8 & 14.2 & 15.64 & 0.94 \\
\hline 5 & 20 & 21.3 & 21.7 & 20.1 & 21.2 & 20.2 & 20.90 & 0.71 \\
\hline 6 & 25 & 26.1 & 26.2 & 25.3 & 26.2 & 25.1 & 25.78 & 0.54 \\
\hline 7 & 30 & 31.2 & 31.3 & 30.4 & 31.2 & 30.3 & 30.88 & 0.49 \\
\hline 8 & 35 & 36.3 & 36.8 & 35.4 & 36.3 & 35.1 & 35.98 & 0.70 \\
\hline 9 & 40 & 40.7 & 41.7 & 40.8 & 41.7 & 40.6 & 41.10 & 0.55 \\
\hline 10 & 45 & 46.1 & 47.1 & 44.9 & 45.4 & 45.1 & 45.72 & 0.90 \\
\hline 11 & 50 & 50.7 & 51.9 & 49.7 & 51.2 & 50.1 & 50.72 & 0.87 \\
\hline 12 & 55 & 55.3 & 55.8 & 55.7 & 56.3 & 56.7 & 55.96 & 0.55 \\
\hline 13 & 60 & 60.3 & 60.3 & 60.2 & 61.1 & 59.4 & 60.26 & 0.60 \\
\hline 14 & 65 & 65.2 & 65.2 & 64.8 & 65.3 & 65.8 & 65.26 & 0.36 \\
\hline 15 & 70 & 69.8 & 70.8 & 69.6 & 69.7 & 70.2 & 70.02 & 0.49 \\
\hline \multicolumn{8}{|c|}{ Simpangan Rata - Rata } & 0.62 \\
\hline
\end{tabular}




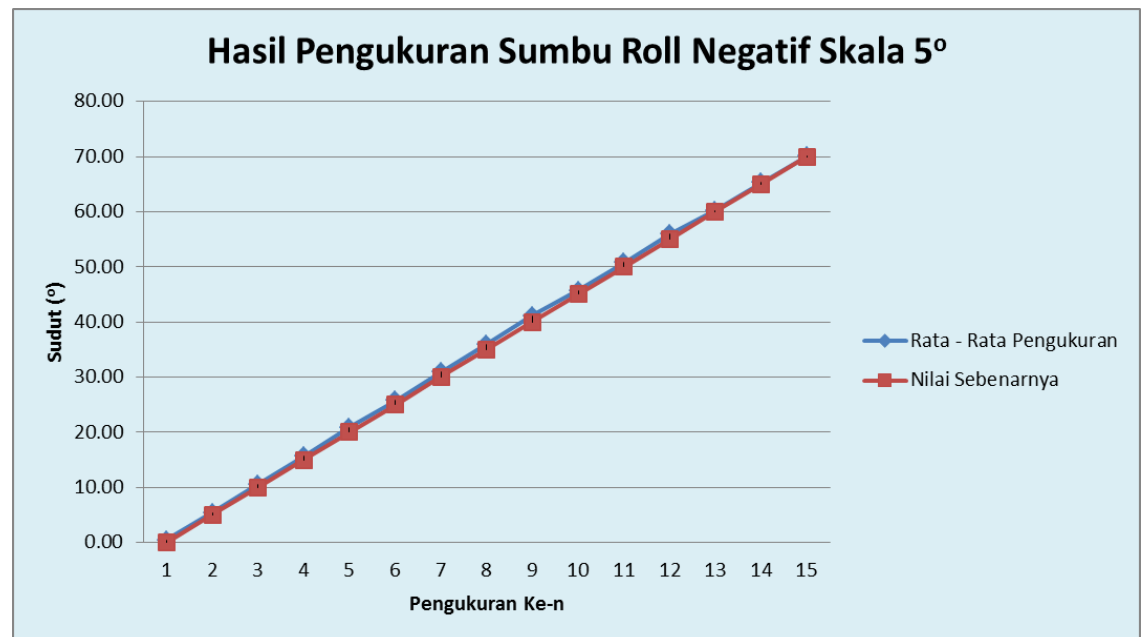

Gambar 14. Grafik rotasi pada sumbu x (roll) negatif Skala pengukuran $5^{0}$

Hasil pengukuran rotasi pada sumbu $x$ (rol/) negatif pada skala $5^{\circ}$ diperoleh simpangan rata - rata sebesar 0,62 ${ }^{\circ}$ terhadap nilai sebenarnya. Pada Gambar 14 dapat dilihat bahwa hasil pengukuran sudah mendekati nilai sebenarnya dengan simpangan terbesar pada pengkuran $15^{\circ}$ dengan simpangan sebesar $0,94^{\circ}$.

Tabel 4. Tabel rotasi pada sumbu x (roll) negatif skala pengukuran $\mathbf{1 0}^{\circ}$

\begin{tabular}{|c|c|c|c|c|c|c|c|c|}
\hline \multirow{3}{*}{ No } & \multirow{3}{*}{$\begin{array}{c}\text { Nilai } \\
\text { Sebenarnya }\end{array}$} & \multicolumn{7}{|c|}{ Hasil Pengukuran Skala Pengukur $10^{\circ}$ Sumbu Negatif } \\
\hline & & \multicolumn{5}{|c|}{ Pengukuran Ke-n } & \multicolumn{2}{|c|}{ Rata Rata } \\
\hline & & $\mathrm{Ke}-1$ & ke-2 & ke-3 & $\mathrm{Ke}-4$ & $\mathrm{Ke}-5$ & Pengukuran & simpangan \\
\hline 1 & 0 & 0.4 & 0.5 & 0.5 & 0.2 & 0.4 & 0.40 & 0.12 \\
\hline 2 & 10 & 11.5 & 9.5 & 10.8 & 10.3 & 9.7 & 10.36 & 0.82 \\
\hline 3 & 20 & 20.3 & 20.4 & 21.1 & 20.9 & 20.4 & 20.62 & 0.36 \\
\hline 4 & 30 & 30.6 & 29.7 & 31.8 & 31.7 & 29.7 & 30.70 & 1.03 \\
\hline 5 & 40 & 41.7 & 41.2 & 41.3 & 41.8 & 40.1 & 41.22 & 0.68 \\
\hline 6 & 50 & 50.7 & 51.3 & 51.2 & 51.4 & 50.1 & 50.94 & 0.54 \\
\hline 7 & 60 & 61.1 & 59.6 & 60.8 & 61.5 & 59.7 & 60.54 & 0.85 \\
\hline 8 & 70 & 71.2 & 70.3 & 70.4 & 71.6 & 69.8 & 70.66 & 0.73 \\
\hline \multicolumn{8}{|c|}{ Simpangan Rata - Rata } & 0.64 \\
\hline
\end{tabular}

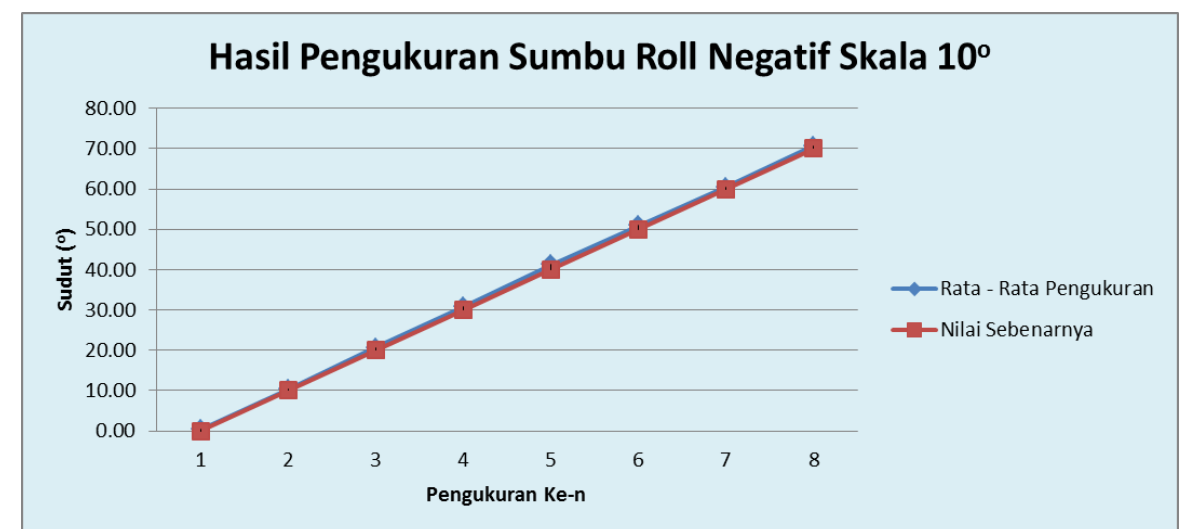

Gambar 15. Grafik rotasi pada sumbu x (roll) negatif Skala pengukuran $10^{\circ}$

Hasil pengukuran rotasi pada sumbu x (rol/) negatif pada skala $10^{\circ}$ diperoleh simpangan rata - rata sebesar $0,64^{\circ}$ terhadap nilai sebenarnya. Pada Gambar 15 dapat dilihat bahwa hasil 
pengukuran sudah mendekati nilai sebenarnya dengan simpangan terbesar pada pengkuran $30^{\circ}$ dengan simpangan sebesar $1,03^{\circ}$.

Data hasil pengukuran rotasi pada sumbu $x$ (rol/) positif dan sumbu negatif diperoleh Hasil pengukuran yang sudah mendekati nilai sebenarnya dengan simpangan rata - rata sebesar $0,58^{\circ}$. Hasil pengkuran ini adalah gabungan hasil pengkuran dari gyroscope dan accelerometer

Dapat disimpulkan Alat pendeteksi sikap (attitude) bisa digunakan untuk mendeteksi rotasi sumbu x (rol) pada wahana terbang. Hal tersebut berdasarkan pada analisis bahwa hasil pengkuran sudah mendekati nilai sebenarnya dengan simpangan rata - rata sebesar $0,58^{\circ}$ derajat. Sehingga alat ini mampu untuk membedakan sudut $0^{\circ}, 15^{\circ}, 30^{\circ}$ dan $45^{\circ}$.

\section{b. Rotasi pada sumbu y (pitch)}

Rotasi pada sumbu y (pitch) searah jarum jam merupakan rotasi pada sumbu positif atau pergerakan wahana terbang adalah menukik ke atas. Sedangkan rotasi pada sumbu x (roll) berlawanan dengan jarum jam merupakan rotasi pada sumbu negatif atau pergerakan wahana terbang adalah menukik ke bawah. Data hasil pengukuran rotasi adalah sebagai berikut :

\section{b.1 Rotasi pada sumbu y (pitch) positif}

Tabel 5. Tabel rotasi pada sumbu y (pitch) positif skala pengukuran $\mathbf{5}^{0}$

\begin{tabular}{|c|c|c|c|c|c|c|c|c|}
\hline \multirow{3}{*}{ No } & \multirow{3}{*}{$\begin{array}{c}\text { Nilai } \\
\text { Sebenarnya }\end{array}$} & \multicolumn{7}{|c|}{ Hasil Pengukuran Skala Pengukur $5^{\circ}$ Sumbu Positif } \\
\hline & & \multicolumn{5}{|c|}{ Pengukuran Ke-n } & \multicolumn{2}{|c|}{ Rata Rata } \\
\hline & & $\mathrm{Ke}-1$ & ke-2 & $\mathrm{ke}-3$ & $\mathrm{Ke}-4$ & $\mathrm{Ke}-5$ & Pengukuran & simpangan \\
\hline 1 & 0 & 0.6 & 0.7 & 0.7 & 0.7 & 0.3 & 0.60 & 0.17 \\
\hline 2 & 5 & 5.2 & 5.2 & 5.7 & 5.2 & 4.3 & 5.12 & 0.51 \\
\hline 3 & 10 & 10.7 & 10.8 & 10.7 & 10.3 & 10.6 & 10.62 & 0.19 \\
\hline 4 & 15 & 16.4 & 15.8 & 15.9 & 15.8 & 15.7 & 15.92 & 0.28 \\
\hline 5 & 20 & 20.9 & 21.5 & 21 & 21.1 & 20.4 & 20.98 & 0.40 \\
\hline 6 & 25 & 26.7 & 26.3 & 25.4 & 26.5 & 25.3 & 26.04 & 0.65 \\
\hline 7 & 30 & 31.8 & 31.7 & 31.3 & 30.9 & 30.1 & 31.16 & 0.69 \\
\hline 8 & 35 & 36.6 & 37.2 & 37.2 & 36.8 & 35.8 & 36.72 & 0.58 \\
\hline 9 & 40 & 42.4 & 41.9 & 42.2 & 42.2 & 40.4 & 41.82 & 0.81 \\
\hline 10 & 45 & 46.6 & 47.2 & 46.7 & 47.3 & 44.7 & 46.50 & 1.05 \\
\hline 11 & 50 & 51.7 & 52.7 & 51.8 & 52.1 & 49.8 & 51.62 & 1.09 \\
\hline 12 & 55 & 56.5 & 57.6 & 56.8 & 57.8 & 54.3 & 56.60 & 1.39 \\
\hline 13 & 60 & 62.5 & 61.2 & 61.9 & 61.1 & 59.2 & 61.18 & 1.24 \\
\hline 14 & 65 & 67.8 & 67.8 & 67.3 & 67.4 & 64.8 & 67.02 & 1.26 \\
\hline 15 & 70 & 72.6 & 73.1 & 72.2 & 72.2 & 69.4 & 71.90 & 1.45 \\
\hline \multicolumn{8}{|c|}{ Simpangan Rata - Rata } & 0.78 \\
\hline
\end{tabular}

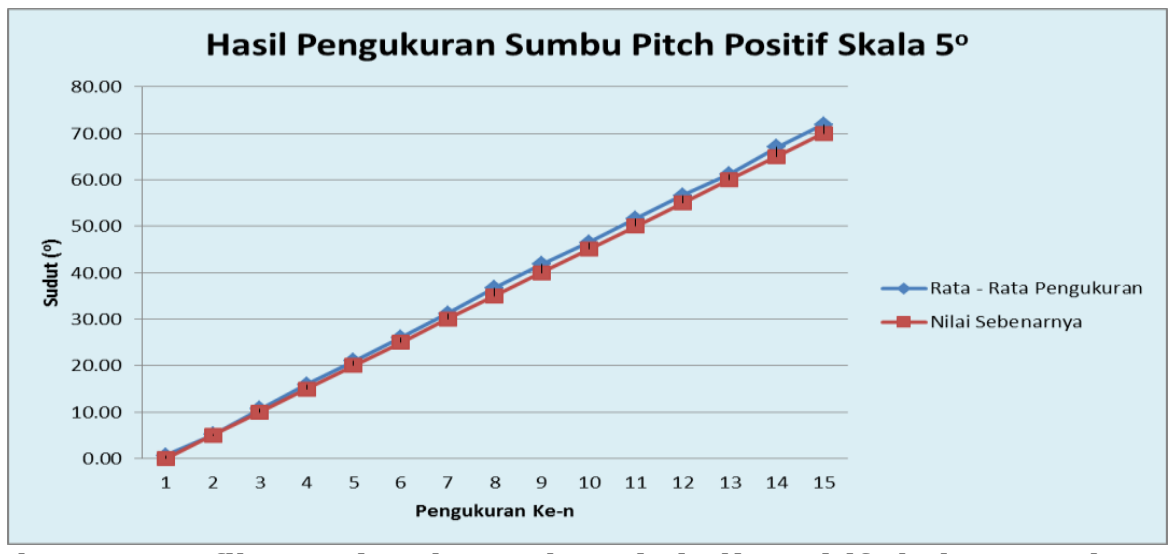

Gambar 16. Grafik rotasi pada sumbu y (pitch) positif skala pengukuran $\mathbf{5}^{0}$ 
Hasil pengukuran rotasi pada sumbu y ( itch) positif pada skala $5^{\circ}$ diperoleh simpangan rata - rata sebesar 0,78 terhadap nilai sebenarnya. Pada Gambar 16 dapat dilihat bahwa hasil pengukuran sudah mendekati nilai sebenarnya dengan simpangan terbesar pada pengkuran $15^{\circ}$ dengan simpangan sebesar $1,45^{\circ}$.

Tabel 6. Tabel rotasi pada sumbu y (pitch) positif skala pengukuran $10^{\circ}$

\begin{tabular}{|c|c|c|c|c|c|c|c|c|}
\hline \multirow{2}{*}{ No } & \multirow{2}{*}{$\begin{array}{c}\text { Nilai } \\
\text { Sebenarnya }\end{array}$} & \multicolumn{8}{|c|}{ Pasil Pengukuran Skala Pengukur $10^{\circ}$ Sumbu Positif } \\
\cline { 3 - 9 } & & Ke-1 & ke-2 & ke-3 & Ke-4 & Ke-5 & Pengukuran & simpangan \\
\hline 1 & 0 & 0.7 & 0.7 & 0.7 & 0.7 & 0.6 & 0.68 & 0.04 \\
\hline 2 & 10 & 10.5 & 11.2 & 10.7 & 10.9 & 10.3 & 10.72 & 0.35 \\
\hline 3 & 20 & 21.1 & 21.4 & 21.2 & 20.8 & 20.5 & 21 & 0.35 \\
\hline 4 & 30 & 31.5 & 31.7 & 31.9 & 30.9 & 30.3 & 31.26 & 0.65 \\
\hline 5 & 40 & 41.9 & 42.2 & 42.2 & 41.8 & 40.3 & 41.68 & 0.79 \\
\hline 6 & 50 & 51.6 & 51.9 & 51.6 & 51.3 & 49.7 & 51.22 & 0.88 \\
\hline 7 & 60 & 61.8 & 62.7 & 62.1 & 61.3 & 59.5 & 61.48 & 1.22 \\
\hline 8 & 70 & 72.1 & 72.2 & 71.8 & 71.2 & 70.1 & 71.48 & 0.86 \\
\hline \multicolumn{8}{|c|}{ Simpangan Rata - Rata } \\
\hline
\end{tabular}

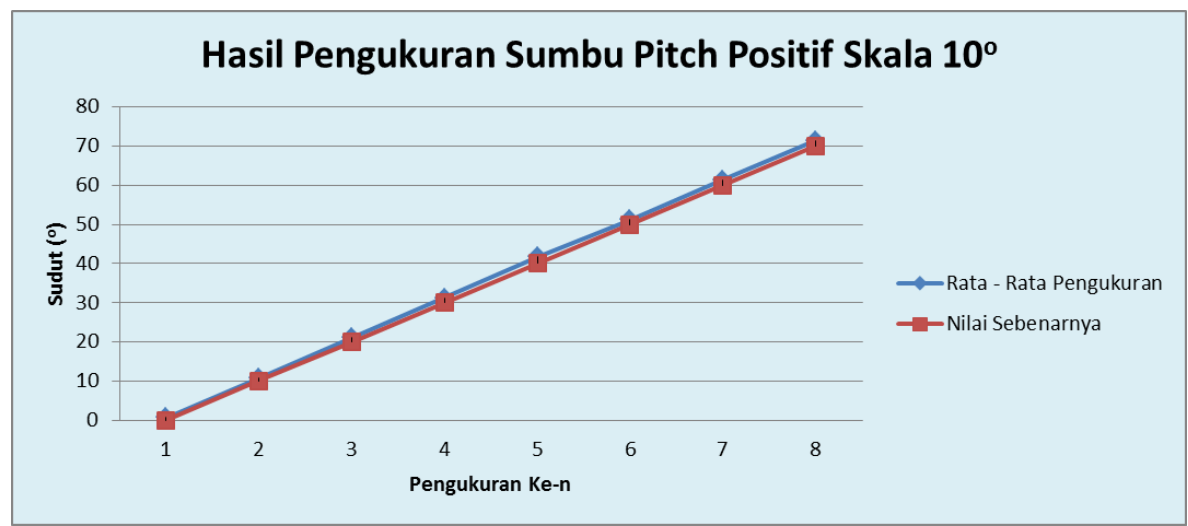

Gambar 17. Grafik rotasi pada sumbu y (pitch) positif skala pengukuran $10^{\circ}$

Hasil pengukuran rotasi pada sumbu y (pitch) positif pada skala $10^{\circ}$ diperoleh simpangan rata - rata sebesar 0,64 terhadap nilai sebenarnya. Pada Gambar 17 dapat dilihat bahwa hasil pengukuran sudah mendekati nilai sebenarnya dengan simpangan terbesar pada pengkuran $60^{\circ}$ dengan simpangan sebesar $1,22^{\circ}$.

\section{B.2 Rotasi pada sumbu y (pitch) negatif}

Tabel 7. Tabel rotasi pada sumbu y (pitch) negatif skala pengukuran $\mathbf{5}^{\mathbf{0}}$

\begin{tabular}{|c|c|c|c|c|c|c|c|c|}
\hline \multirow{3}{*}{ No } & \multirow{3}{*}{$\begin{array}{c}\text { Nilai } \\
\text { Sebenarnya }\end{array}$} & \multicolumn{7}{|c|}{ Hasil Pengukuran Skala Pengukur $5^{\circ}$ Sumbu Negatif } \\
\hline & & \multicolumn{5}{|c|}{ Pengukuran Ke-n } & \multicolumn{2}{|c|}{ Rata Rata } \\
\hline & & Ke-1 & ke-2 & $\mathrm{ke}-3$ & $\mathrm{Ke}-4$ & Ke-5 & Pengukuran & simpangan \\
\hline 1 & 0 & 0.1 & 0.2 & 0.1 & 0.1 & 0.4 & 0.18 & 0.13 \\
\hline 2 & 5 & 4.4 & 4.3 & 4.4 & 4.3 & 5.1 & 4.50 & 0.34 \\
\hline 3 & 10 & 9 & 9.2 & 9.4 & 9.7 & 10.4 & 9.54 & 0.55 \\
\hline 4 & 15 & 13.8 & 15.3 & 14.2 & 14.2 & 14.9 & 14.48 & 0.61 \\
\hline 5 & 20 & 19.2 & 19.5 & 19.9 & 19.5 & 19.7 & 19.56 & 0.26 \\
\hline 6 & 25 & 24.3 & 24.4 & 24.9 & 24.6 & 24.4 & 24.52 & 0.24 \\
\hline 7 & 30 & 29.7 & 29.6 & 30.8 & 29.9 & 30.6 & 30.12 & 0.54 \\
\hline 8 & 35 & 35.2 & 35.4 & 35.2 & 36.5 & 35.5 & 35.56 & 0.54 \\
\hline 9 & 40 & 40.4 & 40.4 & 40.9 & 40.9 & 40.3 & 40.58 & 0.29 \\
\hline 10 & 45 & 45.3 & 45.3 & 45.1 & 45.6 & 45.2 & 45.30 & 0.19 \\
\hline 11 & 50 & 50.1 & 50.3 & 50.6 & 50.4 & 50.4 & 50.36 & 0.18 \\
\hline 12 & 55 & 56.1 & 55.6 & 55.6 & 56.3 & 55.7 & 55.86 & 0.32 \\
\hline 13 & 60 & 60.8 & 61.2 & 60.9 & 60.7 & 61.1 & 60.94 & 0.21 \\
\hline 14 & 65 & 66.3 & 66.2 & 66.1 & 65.9 & 65.7 & 66.04 & 0.24 \\
\hline 15 & 70 & 72.2 & 71.7 & 71.4 & 71.3 & 70.8 & 71.48 & 0.52 \\
\hline & & & Simp & $\operatorname{san} \mathrm{Ra}$ & Rata & & & 0.34 \\
\hline
\end{tabular}




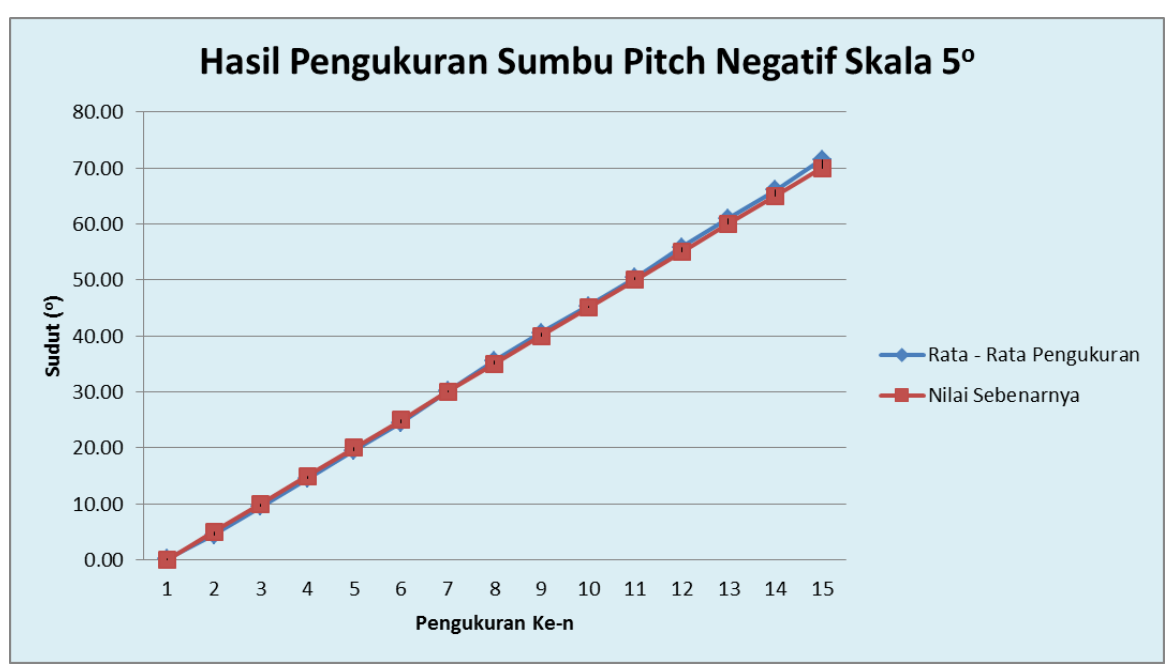

Gambar 18. Grafik rotasi pada sumbu y (pitch) negatif skala pengukuran $5^{0}$

Hasil pengukuran rotasi pada sumbu y (pitch) negatif pada skala $5^{\circ}$ diperoleh simpangan rata - rata sebesar $0,34^{\circ}$ terhadap nilai sebenarnya. Pada Gambar 18 dapat dilihat bahwa hasil pengukuran sudah mendekati nilai sebenarnya dengan simpangan terbesar pada pengkuran $15^{\circ}$ dengan simpangan sebesar $0,61^{\circ}$.

Tabel 8. Tabel rotasi pada sumbu y (pitch) negatif skala pengukuran $\mathbf{1 0}^{\circ}$

\begin{tabular}{|c|c|c|c|c|c|c|c|c|}
\hline \multirow{2}{*}{ No } & Nilai & \multicolumn{6}{|c|}{ Hasil Pengukuran Skala Pengukur $10^{\circ}$ Sumbu Negatif } \\
\cline { 3 - 9 } & Sebenarnya & \multicolumn{6}{|c|}{ Pengukuran Ke-n } & \multicolumn{3}{c|}{ Rata Rata } \\
\cline { 3 - 9 } & & Ke-1 & ke-2 & ke-3 & Ke-4 & Ke-5 & Pengukuran & simpangan \\
\hline 1 & 0 & 0.1 & 0.2 & 0.1 & 0.2 & 0.7 & 0.26 & 0.25 \\
\hline 2 & 10 & 9.3 & 10.3 & 9.8 & 9.2 & 9.7 & 9.66 & 0.44 \\
\hline 3 & 20 & 19.6 & 20 & 19.7 & 19.4 & 20.4 & 19.82 & 0.39 \\
\hline 4 & 30 & 29.6 & 30.3 & 30.3 & 29.8 & 30.4 & 30.08 & 0.36 \\
\hline 5 & 40 & 40.8 & 41.3 & 41 & 41.1 & 40.8 & 41.00 & 0.21 \\
\hline 6 & 50 & 50.5 & 50.9 & 50.7 & 50.2 & 49.4 & 50.34 & 0.59 \\
\hline 7 & 60 & 61.1 & 61.2 & 61.1 & 61.1 & 60.3 & 60.96 & 0.37 \\
\hline 8 & 70 & 71.7 & 71.2 & 71.7 & 72 & 71.8 & 71.68 & 0.29 \\
\hline \multicolumn{8}{|c|}{ Simpangan Rata - Rata } \\
\hline
\end{tabular}

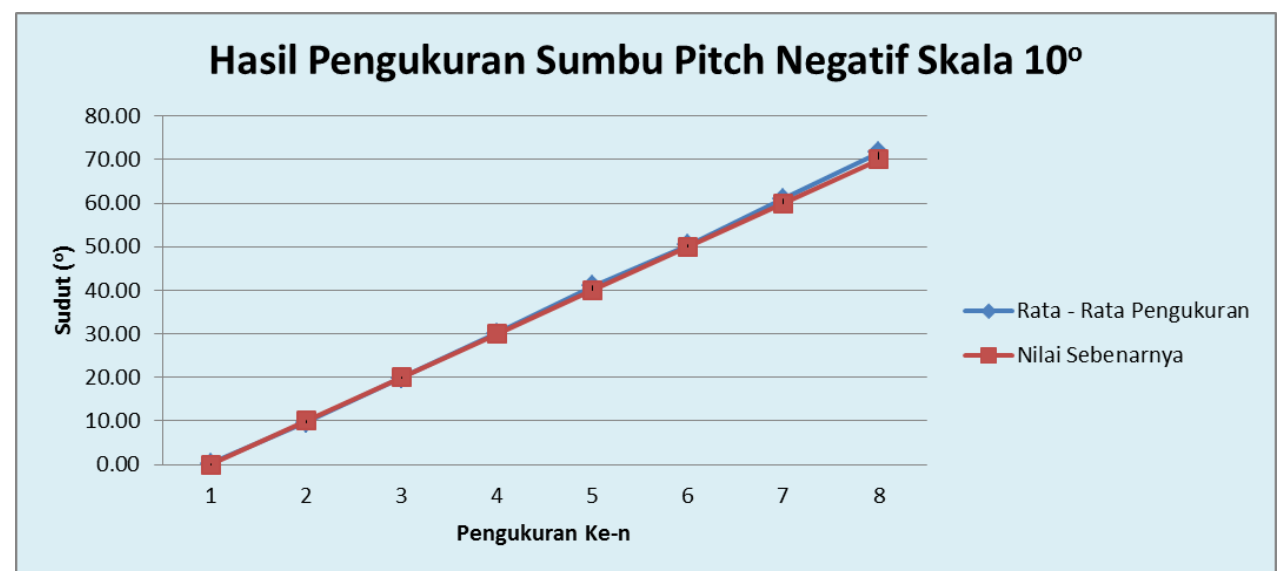

Gambar 19. Grafik rotasi pada sumbu y (pitch) negatif skala pengukuran $10^{\circ}$

Hasil pengukuran rotasi pada sumbu y (pitch) negatif pada skala $10^{\circ}$ diperoleh simpangan rata - rata sebesar $0,36^{\circ}$ terhadap nilai sebenarnya. Pada Gambar 19 dapat dilihat bahwa 
hasil pengukuran sudah mendekati nilai sebenarnya dengan simpangan terbesar pada pengkuran $50^{\circ}$ dengan simpangan sebesar $0,59^{\circ}$.

Data hasil pengukuran rotasi pada sumbu y ( $p$ itch) positif dan sumbu negatif diperoleh Hasil pengukuran yang sudah mendekati nilai sebenarnya dengan simpangan rata - rata sebesar $0,53^{\circ}$. Hasil pengkuran ini adalah gabungan hasil pengkuran dari gyroscope dan accelerometer. Dapat disimpulkan Alat pendeteksi sikap (attitude) bisa digunakan untuk mendeteksi rotasi sumbu y (pitch) pada wahana terbang. Hal tersebut berdasarkan pada analisis bahwa hasil pengkuran sudah mendekati nilai sebenarnya dengan simpangan rata rata sebesar $0,53^{\circ}$ derajat. Sehingga alat ini mampu untuk membedakan sudut $0^{\circ}, 15^{\circ}, 30^{\circ}$ dan $45^{\circ}$.

\section{Rotasi pada sumbu z (yaw)}

Rotasi pada sumbu z (yaw) searah jarum jam merupakan rotasi pada sumbu positif. Sedangkan rotasi pada sumbu x (rol) berlawanan dengan jarum jam merupakan rotasi pada sumbu negatif. Data hasil pengukuran rotasi adalah sebagai berikut :

\section{C.1 Rotasi pada sumbu z (yaw) positif}

Tabel 9. Tabel rotasi pada sumbu $\mathbf{z}$ (yaw) positif skala pengukuran $\mathbf{5}^{0}$

\begin{tabular}{|c|c|c|c|c|c|c|c|c|}
\hline \multirow{3}{*}{ No } & \multirow{3}{*}{$\begin{array}{c}\text { Nilai } \\
\text { Sebenarnya }\end{array}$} & \multicolumn{7}{|c|}{ Hasil Pengukuran Skala Pengukur $5^{\circ}$ Sumbu Positif } \\
\hline & & \multicolumn{5}{|c|}{$\begin{array}{l}\text { Pengukuran Ke-n } \\
\end{array}$} & \multicolumn{2}{|c|}{ Rata Rata } \\
\hline & & Ke-1 & ke-2 & ke-3 & Ke-4 & Ke-5 & Pengukuran & simpangan \\
\hline 1 & 0 & 0 & 0 & 0.7 & 0 & 0 & 0.14 & 0.31 \\
\hline 2 & 5 & 8.26 & 2.6 & 6.8 & 5.3 & 5.2 & 5.63 & 2.11 \\
\hline 3 & 10 & 11.12 & 1.7 & 9.7 & 10.1 & 9.1 & 8.34 & 3.79 \\
\hline 4 & 15 & 14.6 & 8.2 & 13.7 & 7.8 & 17.6 & 12.38 & 4.25 \\
\hline 5 & 20 & 20.3 & 10.8 & 13.1 & 12.1 & 26.6 & 16.58 & 6.70 \\
\hline 6 & 25 & 25.2 & 10.41 & 17.9 & 16.5 & 33.8 & 20.76 & 8.99 \\
\hline 7 & 30 & 30.9 & 11 & 21.7 & 17.7 & 36.6 & 23.58 & 10.24 \\
\hline 8 & 35 & 31.7 & 15.9 & 26.1 & 25.5 & 42.1 & 28.26 & 9.60 \\
\hline 9 & 40 & 41.7 & 20.3 & 29.6 & 28.2 & 46.5 & 33.26 & 10.65 \\
\hline 10 & 45 & 44.9 & 20 & 35.3 & 29.7 & 51.8 & 36.34 & 12.49 \\
\hline 11 & 50 & 53 & 23.3 & 28.9 & 36.3 & 54.1 & 39.12 & 13.96 \\
\hline 12 & 55 & 56.4 & 26.5 & 32.3 & 38.7 & 58.9 & 42.56 & 14.46 \\
\hline 13 & 60 & 61 & 28.6 & 36.3 & 44.8 & 64.1 & 46.96 & 15.38 \\
\hline 14 & 65 & 57.4 & 33.5 & 44.9 & 47.1 & 66.9 & 49.96 & 12.72 \\
\hline 15 & 70 & 61.3 & 36.3 & 53.9 & 52 & 73.4 & 55.38 & 13.58 \\
\hline \multicolumn{8}{|c|}{ Simpangan Rata - Rata } & 9.28 \\
\hline
\end{tabular}

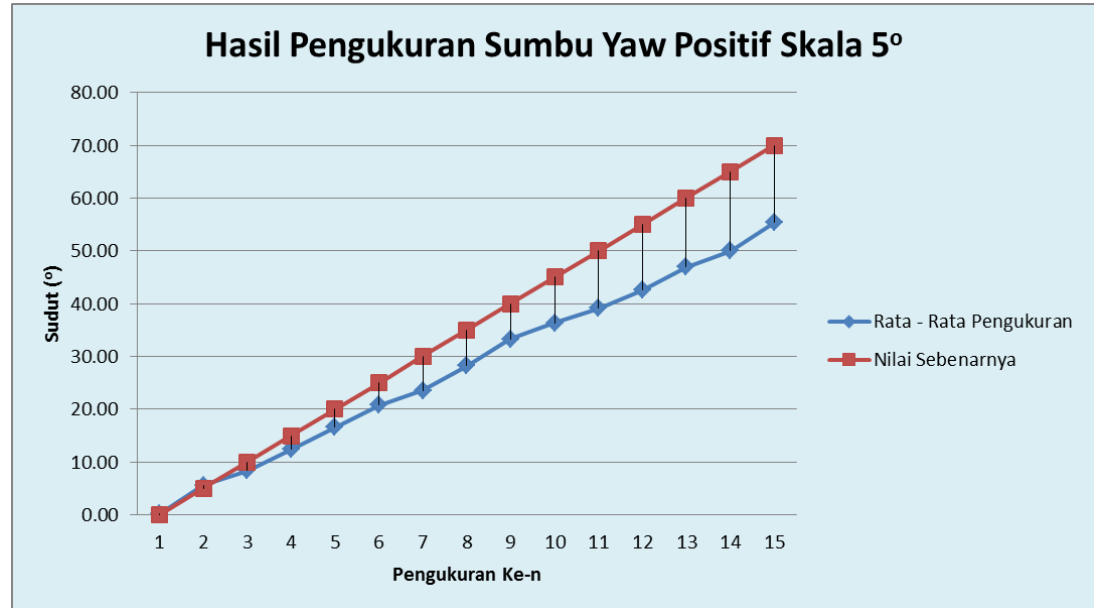

Gambar 20. Grafik rotasi pada sumbu z (yaw) positif skala pengukuran $5^{0}$ 
Hasil pengukuran rotasi pada sumbu z (yaw) positif pada skala $5^{\circ}$ diperoleh simpangan rata - rata sebesar 9,28 terhadap nilai sebenarnya. Pada Gambar 20 dapat dilihat bahwa hasil cenderung menjauhi nilai sebenarnya dengan simpangan terbesar pada pengkuran $55^{\circ}$ dengan simpangan sebesar $14,46^{\circ}$.

Tabel 10. Tabel rotasi pada sumbu z (yaw) positif skala pengukuran $\mathbf{1 0}^{\circ}$

\begin{tabular}{|c|c|c|c|c|c|c|c|c|}
\hline \multirow{2}{*}{ No } & \multirow{2}{*}{$\begin{array}{c}\text { Nilai } \\
\text { Sebenarnya }\end{array}$} & \multicolumn{6}{|c|}{ Penil Pengukuran Skala Pengukur $10^{\circ}$ Sumbu Positif } \\
\cline { 3 - 9 } & & Ke-1 & ke-2 & ke-3 & Ke-4 & Ke-5 & Pengukuran & simpangan \\
\hline 1 & 0 & 0 & 0 & 0 & 0.1 & 0 & 0.02 & 0.04 \\
\hline 2 & 10 & 10.3 & 10.3 & 3.2 & 5.1 & 7.4 & 7.26 & 3.15 \\
\hline 3 & 20 & 16.5 & 13.54 & 12.1 & 16.35 & 17.8 & 15.26 & 2.35 \\
\hline 4 & 30 & 21.6 & 21.7 & 14.1 & 26.4 & 26.9 & 22.14 & 5.15 \\
\hline 5 & 40 & 27.4 & 30 & 25 & 36.9 & 35.7 & 31.00 & 5.17 \\
\hline 6 & 50 & 36.4 & 40.24 & 33.6 & 43.1 & 47.5 & 40.17 & 5.47 \\
\hline 7 & 60 & 41.4 & 49.1 & 39.3 & 53.4 & 57.3 & 48.10 & 7.68 \\
\hline 8 & 70 & 50.6 & 48.1 & 49.5 & 62.4 & 67.9 & 55.70 & 8.89 \\
\hline \multicolumn{8}{|c|}{ Simpangan Rata - Rata } \\
\hline
\end{tabular}

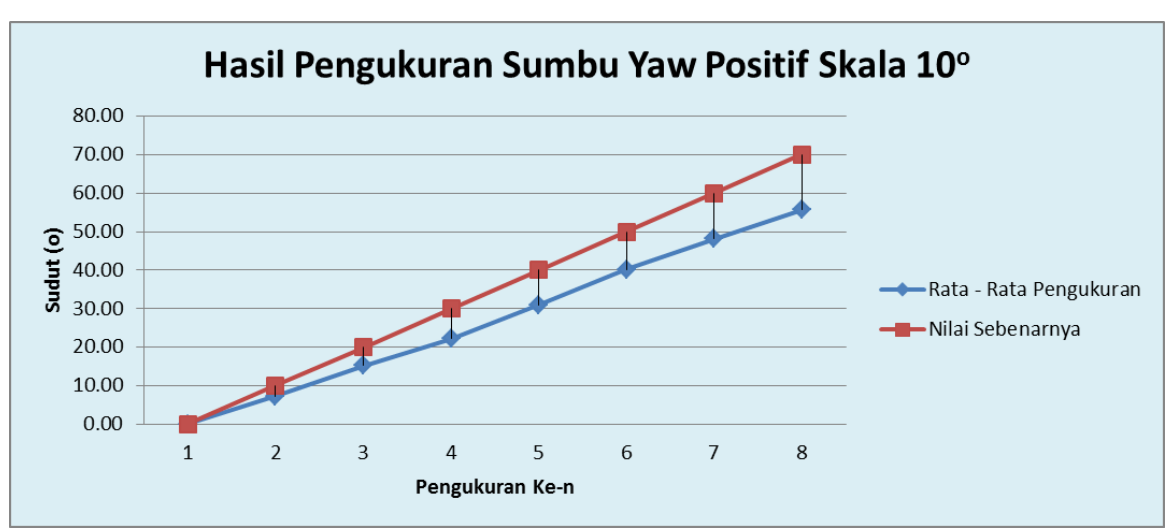

Gambar 21. Grafik rotasi pada sumbu z (yaw) positif skala pengukuran $10^{\circ}$

Hasil pengukuran rotasi pada sumbu z (yaw) positif pada skala $10^{\circ}$ diperoleh simpangan rata - rata sebesar 4,740 terhadap nilai sebenarnya. Pada Gambar 21 dapat dilihat bahwa hasil cenderung menjauhi nilai sebenarnya dengan simpangan terbesar pada pengkuran $70^{\circ}$ dengan simpangan sebesar $8,89^{\circ}$.

\section{c.2 Rotasi pada sumbu z (yaw) negatif}

Tabel 11. Tabel rotasi pada sumbu z ( $y a w)$ negatif skala pengukuran $5^{0}$

\begin{tabular}{|c|c|c|c|c|c|c|c|c|}
\hline \multirow{3}{*}{ No } & \multirow{3}{*}{$\begin{array}{c}\text { Nilai } \\
\text { Sebenarnya }\end{array}$} & \multicolumn{7}{|c|}{ Hasil Pengukuran Skala Pengukur $5^{\circ}$ Sumbu Negatif } \\
\hline & & \multicolumn{5}{|c|}{ Pengukuran Ke-n } & \multicolumn{2}{|c|}{ Rata Rata } \\
\hline & & $\mathrm{Ke}-1$ & ke-2 & ke-3 & Ke-4 & $\mathrm{Ke}-5$ & Pengukuran & simpangan \\
\hline 1 & 0 & 0 & 0 & 0.4 & 1.4 & 0 & 0.36 & 0.61 \\
\hline 2 & 5 & 6.6 & 2.3 & 7.3 & 8.8 & 10.6 & 7.12 & 3.10 \\
\hline 3 & 10 & 11.1 & 7.1 & 10 & 15.2 & 20.4 & 12.76 & 5.17 \\
\hline 4 & 15 & 17.1 & 13.2 & 27.4 & 26 & 26.4 & 22.02 & 6.44 \\
\hline 5 & 20 & 16.5 & 20.2 & 45.1 & 30.9 & 30.2 & 28.58 & 11.15 \\
\hline 6 & 25 & 24.7 & 27 & 54.5 & 38.1 & 35.5 & 35.96 & 11.79 \\
\hline 7 & 30 & 31.1 & 37.1 & 63.1 & 46.3 & 39.4 & 43.40 & 12.28 \\
\hline 8 & 35 & 35.9 & 40.5 & 69 & 53.4 & 44.5 & 48.66 & 13.07 \\
\hline 9 & 40 & 44.6 & 47.5 & 78.1 & 62.9 & 50.1 & 56.64 & 13.88 \\
\hline 10 & 45 & 55.9 & 53.4 & 82.8 & 72.31 & 54.9 & 63.86 & 13.07 \\
\hline 11 & 50 & 60.4 & 64.8 & 83.1 & 85 & 60.6 & 70.78 & 12.26 \\
\hline 12 & 55 & 67.7 & 69.7 & 88.64 & 92.6 & 65.3 & 76.79 & 12.80 \\
\hline 13 & 60 & 71.5 & 77.1 & 96.6 & 97.7 & 69.1 & 82.40 & 13.78 \\
\hline 14 & 65 & 77.2 & 82.6 & 108 & 109 & 69.7 & 89.30 & 18.12 \\
\hline 15 & 70 & 87.1 & 89.1 & 117.9 & 122.8 & 73.1 & 98.00 & 21.38 \\
\hline & & & Simp & $\operatorname{san}$ Rat & Rata & & & 11.26 \\
\hline
\end{tabular}




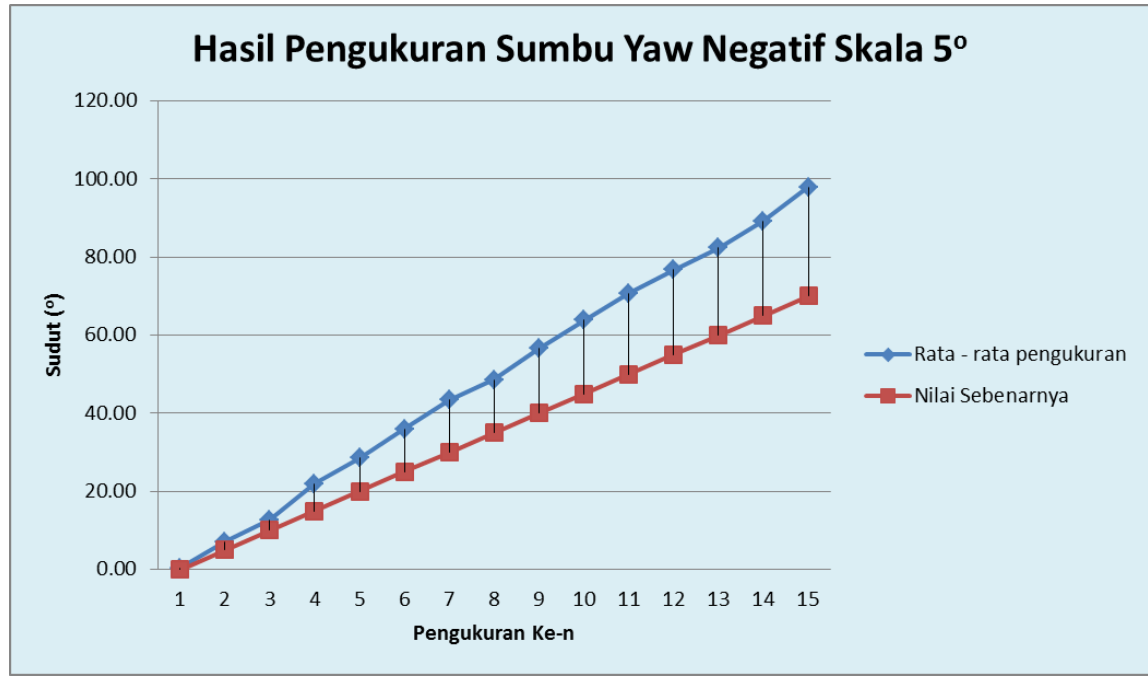

Gambar 22. Grafik rotasi pada sumbu z ( yaw) negatif skala pengukuran $5^{0}$

Hasil pengukuran rotasi pada sumbu z (yaw) negatif pada skala $5^{\circ}$ diperoleh simpangan rata - rata sebesar $11,26^{\circ}$ terhadap nilai sebenarnya. Pada Gambar 22 dapat dilihat bahwa hasil cenderung menjauhi nilai sebenarnya dengan simpangan terbesar pada pengkuran $70^{\circ}$ dengan simpangan sebesar $21,38^{\circ}$.

Tabel 12. Tabel rotasi pada sumbu $z$ (yaw) negatif skala pengukuran $10^{\circ}$

\begin{tabular}{|c|c|c|c|c|c|c|c|c|}
\hline \multirow{3}{*}{ No } & \multirow{3}{*}{$\begin{array}{c}\text { Nilai } \\
\text { Sebenarnya }\end{array}$} & \multicolumn{7}{|c|}{ Hasil Pengukuran Skala Pengukur $10^{\circ}$ Sumbu Negatif } \\
\hline & & \multicolumn{5}{|c|}{ Pengukuran Ke-n } & \multicolumn{2}{|c|}{ Rata Rata } \\
\hline & & Ke-1 & ke-2 & ke-3 & $\mathrm{Ke}-4$ & Ke-5 & Pengukuran & simpangan \\
\hline 1 & 0 & 1.7 & 1.5 & 1.6 & 0.7 & 0.2 & 1.14 & 0.66 \\
\hline 2 & 10 & 14.5 & 9.1 & 14.7 & 12.4 & 7.1 & 11.56 & 3.36 \\
\hline 3 & 20 & 26 & 22.5 & 25 & 25.2 & 17.7 & 23.28 & 3.38 \\
\hline 4 & 30 & 36.7 & 36.4 & 39.5 & 31.5 & 27.6 & 34.34 & 4.74 \\
\hline 5 & 40 & 49.9 & 48.3 & 50.7 & 41.2 & 34.9 & 45.00 & 6.78 \\
\hline 6 & 50 & 62.3 & 53.3 & 53.8 & 50.9 & 45.1 & 53.08 & 6.20 \\
\hline 7 & 60 & 73.9 & 64.5 & 66.7 & 66.4 & 51.8 & 64.66 & 8.03 \\
\hline 8 & 70 & 82.8 & 76.1 & 79.3 & 71.5 & 59.3 & 73.80 & 9.11 \\
\hline \multicolumn{8}{|c|}{ Simpangan Rata - Rata } & 5.28 \\
\hline
\end{tabular}

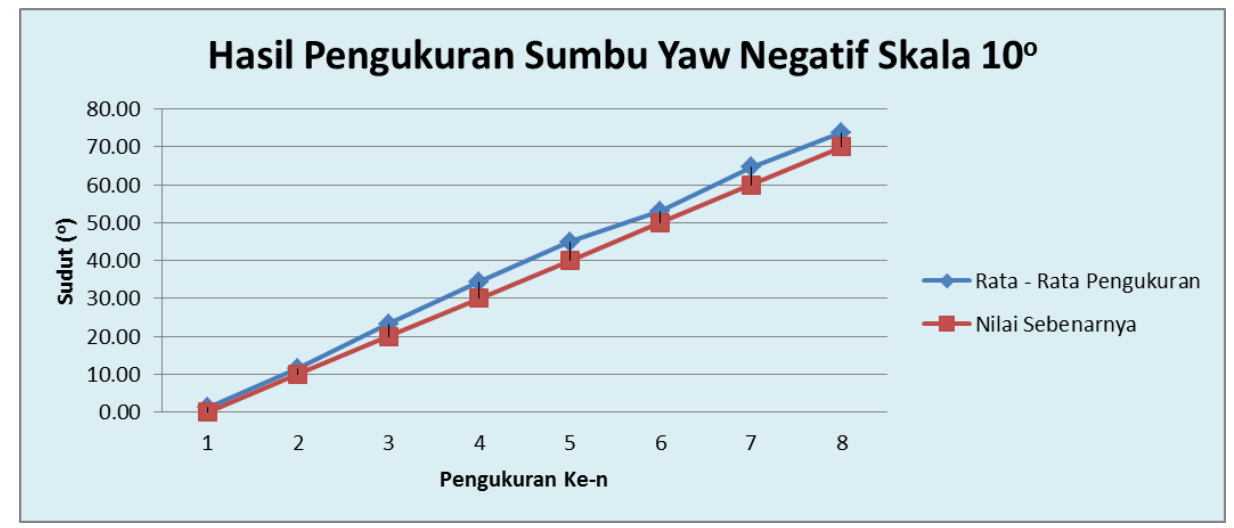

Gambar 23. Grafik rotasi pada sumbu z (yaw) negatif skala pengukuran $10^{\circ}$

Hasil pengukuran rotasi pada sumbu z (yaw) negatif pada skala $10^{\circ}$ diperoleh simpangan rata - rata sebesar 5,28 terhadap nilai sebenarnya. Pada Gambar 23 dapat dilihat bahwa 
hasil cenderung menjauhi nilai sebenarnya dengan simpangan terbesar pada pengkuran $70^{\circ}$ dengan simpangan sebesar $9,11^{\circ}$.

Data hasil pengukuran rotasi pada sumbu z (yaw) positif dan sumbu negatif diperoleh Hasil pengukuran yang sudah mendekati nilai sebenarnya dengan simpangan rata - rata sebesar 7,64 hasil pengkuran ini adalah hasil pengukuran menggunakan gyroscope.

Dapat disimpulkan Alat pendeteksi sikap (attitude) belum layak digunakan untuk mendeteksi rotasi sumbu z (yaw) pada wahana terbang. Hal tersebut berdasarkan pada analisis bahwa hasil pengkuran cendrung menjauhi nilai sebenarnya dengan simpangan rata - rata sebesar $7,64^{\circ}$. Sehingga alat ini tidak mampu untuk membedakan sudut $0^{\circ}, 15^{\circ}, 30^{\circ}$ dan $45^{\circ}$.

Dikatakan tidak mampu adalah batas bawah dan batas atas dari pengukuran sensor pada skala $15^{\circ}$ dibandingkan dengan simpangan rata - rata saling berpotongan. Pada pengukuran $30^{\circ}$ hasil pengukuran dapat menunjukan nilai antara $22,36^{\circ}-37,64^{\circ}$ sedangkan hasil pengukuran $15^{\circ}$ dapat menunjukan hasil antara 7,36 - 22,64 dan hasil pengukuran $30^{\circ}$ dapat menunjukan nilai antara $37,36^{\circ}-52,64^{\circ}$. Dari kemungkinan hasil pengukuran yang saling berpotongan maka alat pendeteksi sikap (attitude) diangap tidak memenuhi spesifikasi untuk digunakan mengukur rotasi sumbu z (yaw) pada wahana terbang.

Pengujian sensor tidak dilakukan dengan menambahkan pengaruh vibrasi yang disebabkan oleh putaran motor pada wahana terbang. Secara teori vibrasi mempengaruhi hasil pengukuran khususnya accelerometer tetapi sebesar apa pengaruh vibrasi tersebut terhadap pengukuran masih memerlukan pengkajian lebih lanjut.

Secara keseluruhan dapat disimpulkan bahwa alat pendeteksi sikap (attitude) sudah dapat digunakan untuk mendeteksi rotasi pada sumbu x (roll) dan y (pitch) pada wahana terbang. Untuk mendeteksi rotasi pada sumbu z (yaw) tidak disarankan untuk menggunakan hasil pengukuran alat ini dikarenakan simpangan yang terlalu besar $\left(7,64^{\circ}\right)$ sehingga tidak memenuhi spesifikasi dari wahana terbang.

\section{KESIMPULAN DAN SARAN}

\subsection{Kesimpulan}

Dari hasil pengukuran dapat ditarik kesimpulan sebagai berikut :

1. Simpangan rata - rata hasil pengukuran rotasi pada sumbu $x$ (rol/) sebesar $0,58^{\circ}$ dan rotasi pada sumbu y (pitch) sebesar $0,53^{\circ}$ sudah memenuhi spesifikasi dari alat pendeteksi sikap, sehingga alat ini layak digunakan untuk mengkur rotasi pada sumbu $\mathrm{x}$ ( roll) dan sumbu y ( $p$ itch) pada wahana terbang. Hal ini berdasarkan pada kemampuan dari alat pendeteksi sikap (attitude) dapat membedakan $0^{\circ}, 15^{\circ}, 30^{\circ}$ dan $45^{\circ}$.

2. Hasil pengukuran gyroscope dan accelerometer yang digabungkan memiliki nilai simpangan rata - rata yang lebih kecil dibandingkan dengan pengukuran menggunakan gyroscope saja. Hal tersebut dibuktikan dengan hasil pengukuran rotasi pada sumbu $\mathrm{x}$ (roll) sebesar $0,58^{\circ}$ dan sumbu y (pitch) sebesar $0,53^{\circ}$ dibandingkan dengan hasil pengukuran rotasi pada sumbu $x$ (yaw) sebesar 7,64.

3. Secara keseluruhan alat pendeteksi sikap (attitude) sudah layak digunakan pada wahana terbang, Hal ini sesuai dengan simpangan rata - rata yang diperoleh dari hasil pengukuran rotasi pada sumbu $x$ (rol/) sebesar $0,58^{\circ}$, rotasi pada sumbu y (pitch) sebesar $0,53^{\circ}$ dan rotasi pada sumbu $z$ (yaw) sebesar $7,64^{\circ}$. 


\subsection{Saran}

Adapun saran untuk pengembangan lebih lanjut sebagai berikut :

1. Pada pengujian alat dibatasi pada gerak rotasi, sehingga pengaruh gerak translasi dan vibrasi yang diakibatkan oleh perputaran motor pada wahana terbang. Sebesar apa pengaruh gerak translasi dan gerak rotasi masih memerlukan pengkajian lebih lanjut.

2. Diperlukan suatu alat/sistem untuk mengkompensasi pengukuran rotasi pada sumbu $z$ (yaw).

3. Pengembangan sistem wireless antara mikrokontroler dengan personal computer. Sehingga dapat digunakan sebagai sistem monitoring pada wahana terbang.

\section{DAFTAR RUJUKAN}

Emmanuel, Dave. (2012). Perancangan dan implementasi alat bantu sistem navigasi menggunakan modul navigasi berbasiskan sistem operasi android. Bandung: Institut Teknologi Nasional.

Hendri Maja Saputra, Zainal Abidi dan Estiko Rijanto. (2013). Imu application in measurement of vehicle position and orientation for controlling a pan-tilt mechanism. Bandung: Lembaga Ilmu Pengetahuan Indonesia.

M. Hasim As'ari, Wahyudi dan Iwan Setiawan. (2009). Pendeteksi sudut menggunakan sensor gyroscope. Semarang: Universitas Diponogoro.

Asep Mubarok, Wahyudi, dan Iwan Setiawan. (2009). Pendeteksi Rotasi Menggunakan Gyroscope Berbasis Mikrokontroler ATmega8535. Semarang: Universitas Indonesia

Christopher J. Fisker. (2010). Using an Accelerometer for Inclination Sensing. Norwood: One Technology Way.

Tuck, Kimberly. (2007). Tilt Sensing Using Linear Accelerometers. Tempe: Freescale Semiconductor.

Pedley, Mark. (2013). Tilt Sensing Using a Three-Axis Accelerometer. Tempe: Freescale Semiconductor.

Jhon P. Bentley. (2005). Principles of Measurement Systems. England: Pearson.

Colton, Shane. (2007). The Balance Filter. USA: Massachusetts Institute of Technology. 